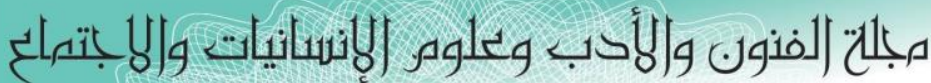

Journal of Arts, Literature, Humanities and Social Sciences

ISSN online: 2414 - 3383

ISSN print: 2616 - 3810

العدد (40) تموز - يوليو 2019

\title{
واقع أبعاد القيادة الريادية في الجامعات السعودية

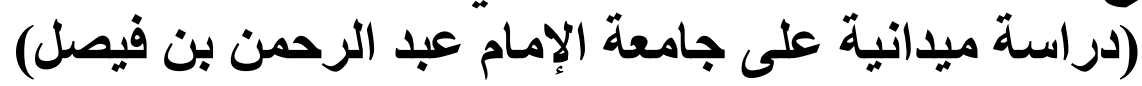

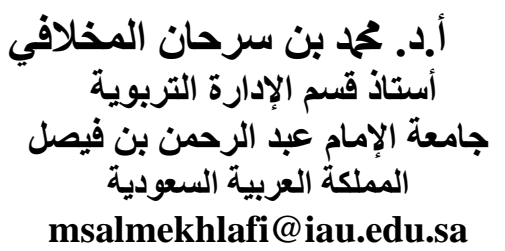

أ.د. تحما بن سرحان المخلافي

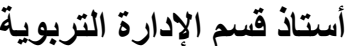

المملكة العربية السعودية الرية

msalmekhlafi@iau.edu.sa
أ. عبير بنت حسن بن عبد الله آل سرحان القحطاني

ماجستير في الإدارة والقيادة التربوية جامعة الإمام عبد الرحمن بن فيصل

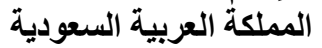
artisticabeer@gmail.com

الخلاصة

هدفت الدراسة إلى التعرف على واقع أبعاد القيادة الريادية (الإبداع الريادي، و الرؤية الاستر اتيجية، و الاستباقية،

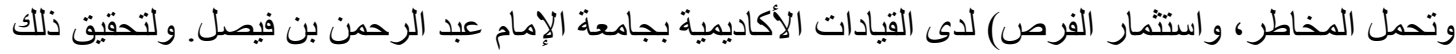

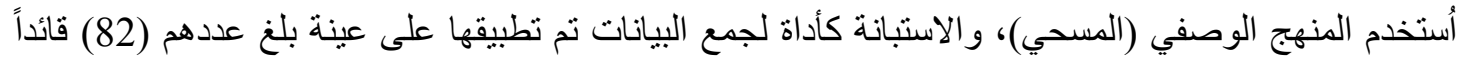

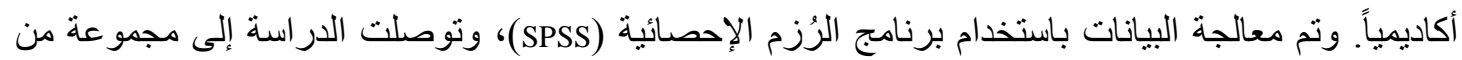

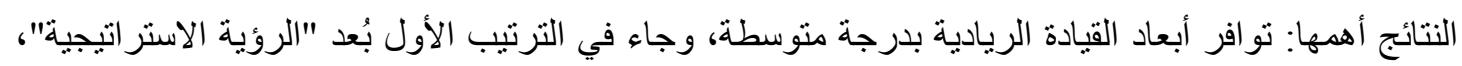

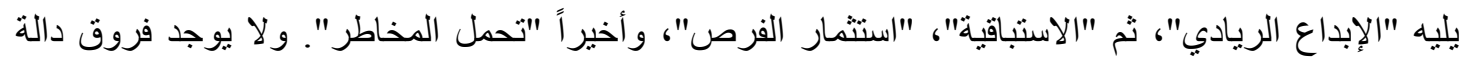

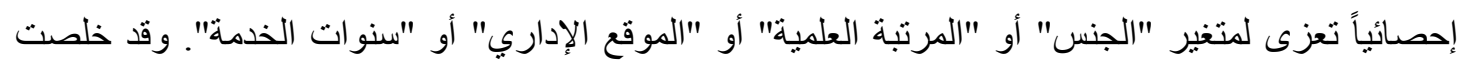

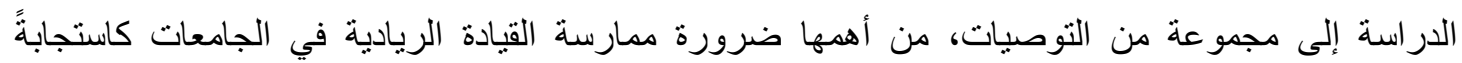

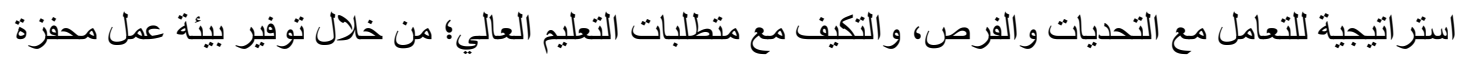
واستقطاب العقول الابتكارية وبناء ثقافة استباقية تنظيمية وتفعيل استر اتيجيات الريادة وتبني بُعد الدخاطرة لنقل الجامعة من موضع استر اتيجي إلى موضع ريادي. 


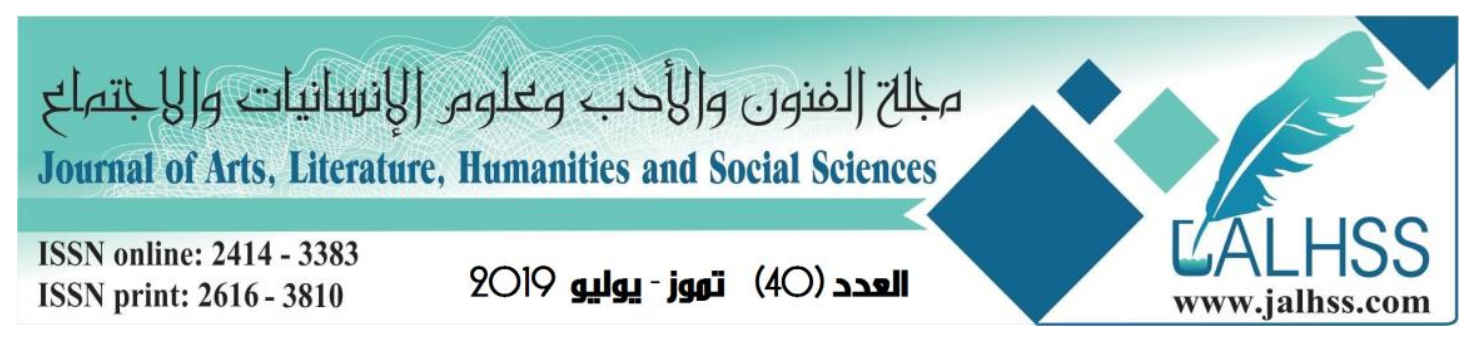

\title{
The Reality of Entrepreneurial Leadership Dimensions in Saudi Universities (An Empirical Study in Imam Abdul Rahman bin Faisal University)
}

\author{
Msc. Abeer Hassan Al-kahtani \\ Master's degree in educational administration and Leadership \\ Imam Abdulrahman bin Faisal University, KSA \\ artisticabeer@gmail.com
}

\author{
Prof. Dr. Mohammed Al - Makhlafi \\ Professor in the Department of Educational Administration at Imam Abdul Rahman \\ bin Faisal University \\ Imam Abdulrahman bin Faisal University, KSA \\ msalmekhlafi@iau.edu.sa
}

\begin{abstract}
The study aimed to identify the reality of Entrepreneurial leadership dimensions (Entrepreneurial innovation, Strategic Vision, Proactiveness, Bear the risks and Investment Opportunities) for academic leaders in the Imam Abdul Rahman bin Faisal University. To achieve this, the study used the analytical descriptive approach, and the questionnaire as a tool for data collection applied to the study sample of 82 academic leaders. The data processed by Statistical Package Program. The study reached several of results: The Entrepreneurial leadership requirements are available in a medium degree, came in the first order "Strategic Vision", followed by the "Entrepreneurial innovation", "Proactiveness", "Investment Opportunities" and finally "bear the risks". There are no significant differences to the variable "gender", "scientific rank" or "administrative location" or "experience years". The study concluded with several recommendations, the most important of which are: The need to exercise entrepreneurial leadership in universities is a strategic response to deal with challenges, opportunities and adapt to the higher education demands. By a stimulating work environment, attracting creativity minds, building a proactive organizational culture, activating entrepreneurial strategies, and adopting risk-taking to move the university from strategic position to an entrepreneurial position.
\end{abstract}




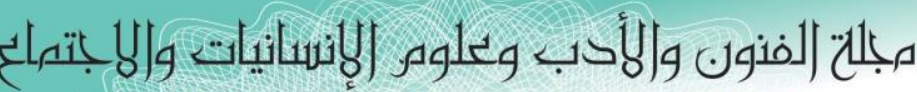
Journal of Arts, Literature, Humanities and Social Sciences

ISSN online: 2414 - 3383

ISSN print: 2616 - 3810

العدد (4O) تموز - يوليو 2019

HALHSS

www.jalhss.com

المـقدمسةة:

بدأت الجامعات حول العالم بالتحول من الدور التقليدي الرئيس بوصفها مصدر اً للتعلم ومجزة للمعرفة العلمية

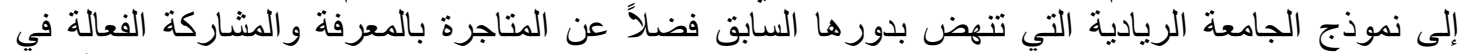

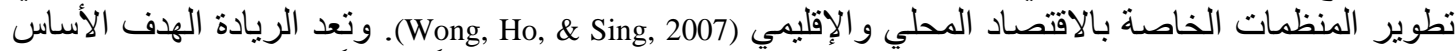
لأدوار الجامعات في الوقت الراهن، حيث تلعب الجامعات الريادية دوراً رئيساً في التطور الاقتصادي

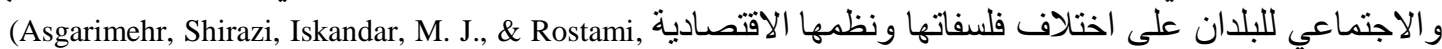
2012). فالجامعات الريادية عبر أنشطتها المتعددة تمهد الطريق للاقتصاد العالمي القائم على المعرفة knowledge-based economy في تحديد وصياغة وحل المشكلات، سواء كان ذلك بشكل فردي أم جماعي، وبذللك تمهد الطريق للتنمية المستدامة

ولمواكبة الريادة الأكاديمية، أطلقت وزارة التعليم بالمملكة العربية السعودية (برنامج الريادة العالمية في الجامعات السعودية) بتاريخ 10-10- 2009م، ويهدف إلى تمكين الجامعات السعودية من تحقيق الريادة و المنافسة العالمية بين جامعات العالم (صائن، 1432). ويتوقف الدور الريادي على وجود قيادة مؤثرة تستطيع أن تُدير هذا الحراك الكئن الإبداعي والمعرفي نحو العالمية.

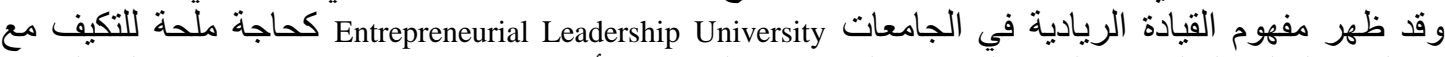
متطلبات التعليم العالي في القرن الحادي والعشرين. فالقيادات الأكاديمية هي قيادات ريادية قادرة على التي التحفيز و الابتكار واستثمار الفرص، ومن ثم فهي مقبلة على التغيير (النفعي، 2012). ولكي تصبح الجامعات ريادية، يبحث أُصحاب المصلحة عن قيادة قوية وخلاقة تمكنها من تطوير ثقافة تكافؤ

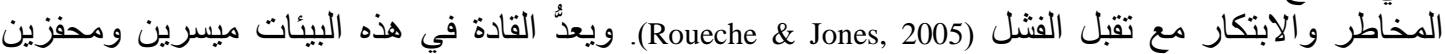
وصناعًا للمعرفة (Floyd \& Mulder, 2006)، و عو املَ تغيير تستطيع أن تتكيف مع تحديات التعليم العالي اليوم .(Crute, 2010)

كما أكد بيكمان وشيرويتز (Beckman \& Cherwitz, 2009:28) على أن الجامعات التي تبحث عن التغيير من خلال القيادة الريادية يجب أن تؤسس منصة فكرية وفلسفة ريادية واسعة النطاق: "يجب أنس أن تمكَّن الأصول الإنسان النسانية

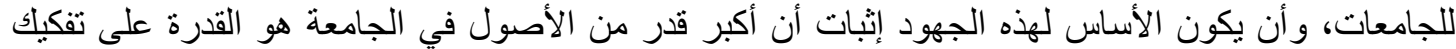

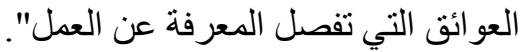

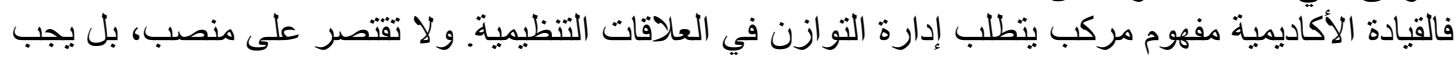

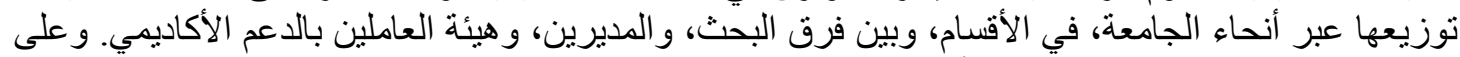

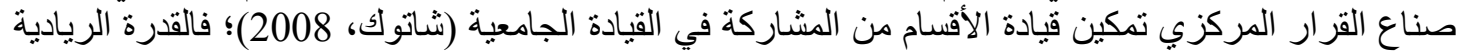

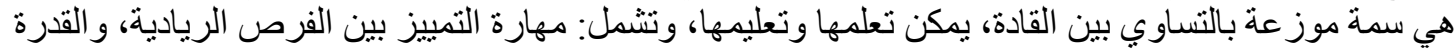

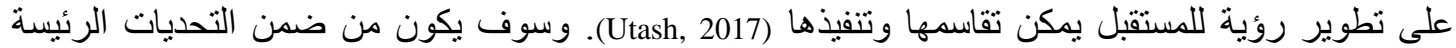

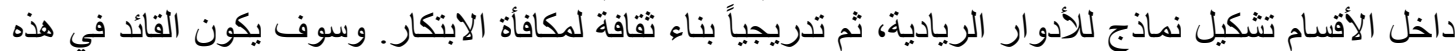

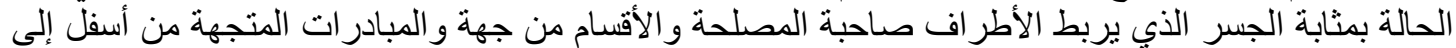

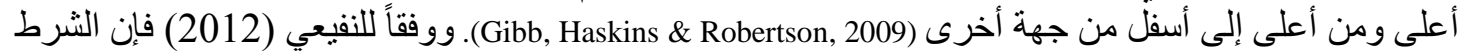
الرئيس للقيادة الجامعية هو المرونة التي يجسدها القائد الريادي على أرض الواقع، ويوجد التوازن في المشهد الأكاديمي. كما تستقطب القيادات الريادية في معظم الجامعات أكبر قدر من الأفر اد من مختلف بلدان العالم سواء كانو ا أساتذة

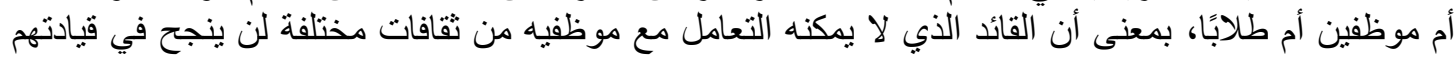

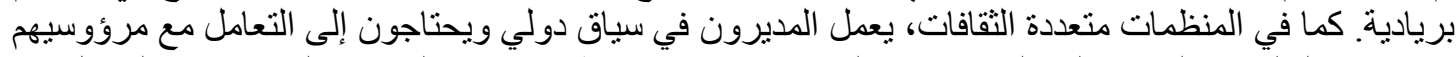

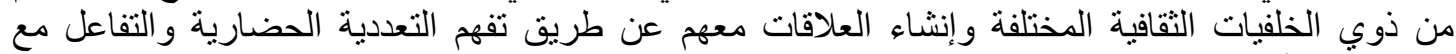
المشاعر والأفكار و السلوكيات المختلفة، ومن ثم القدرة على إلهامهم وتدريبهم من منطلق ثقافتهم (القحطاني،

.2015 
مبلحت (لفنون والأدب وعلوه الإنسانيات والهبانهماع Journal of Arts, Literature, Humanities and Social Sciences

ISSN online: 2414 - 3383

ISSN print: 2616 - 3810

العدد (4O) تموز - يوليو 2019

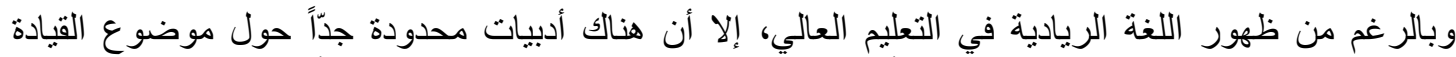

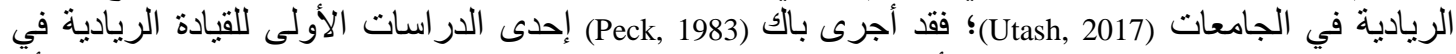

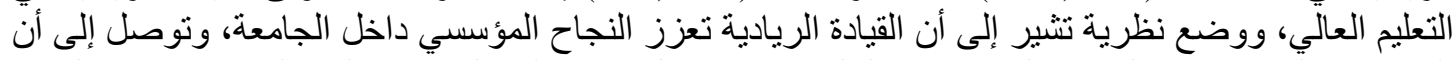

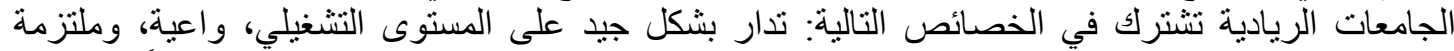

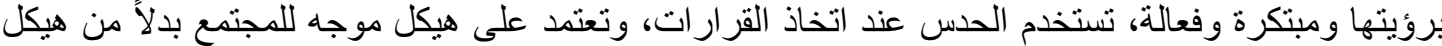
تنظيمي هرمي. كما فحص نيل (Neal, 1998) جو انب الحركة الريادية في التعليم العالي من خلال ملاحظة العديد من القياداد التيات في

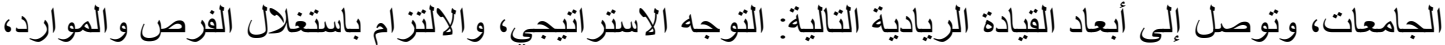

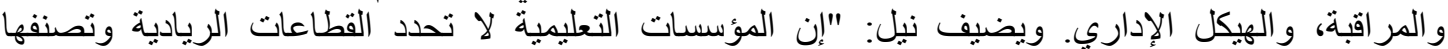

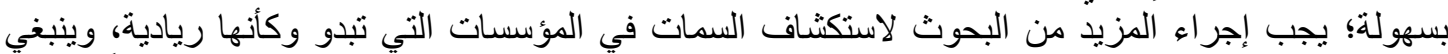

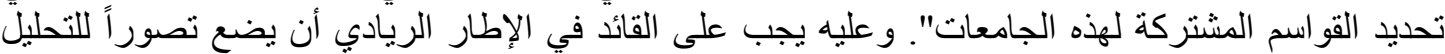

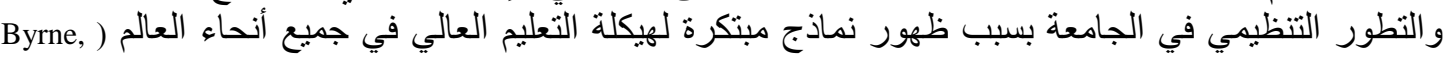

إن تعليم القيادة الريادية في الجامعات يتطلب الموقوف عن كثب على التجارب السابقة وفهم كيفية تطبيقها عملياً

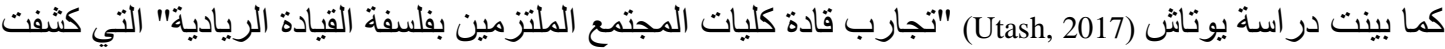

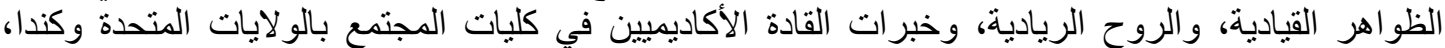

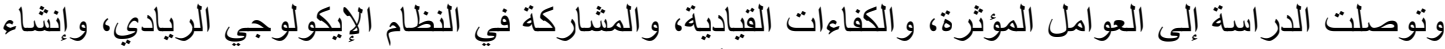

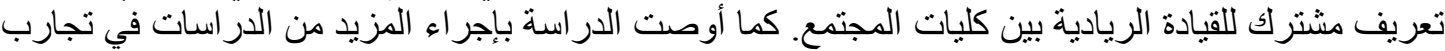

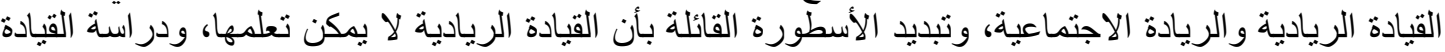

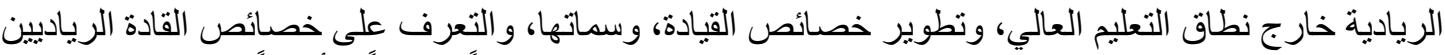
الناجحين، وتوسيع المعرفة لتصبح جهة بناءة للقدرات، و عامل تغيير، و وقائداً تحويلياً، و أخير أ تقييم الاستثمار بناء التياء على العائد. ولتطبيق القيادة الريادية ستحتاج مؤسسات التعليم العالي إلى إعادة النظر في استراتيجياتها التشغيلية لتصبح

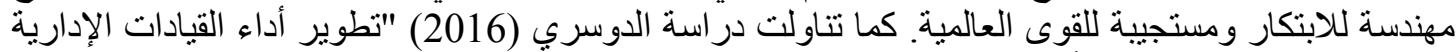

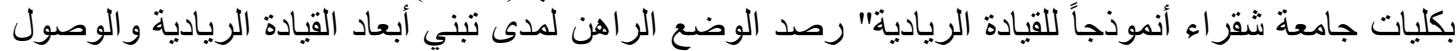

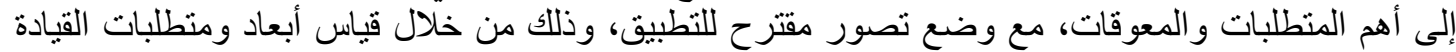

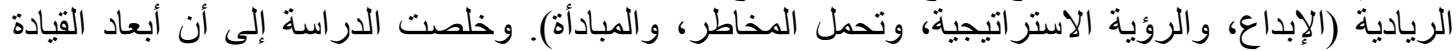

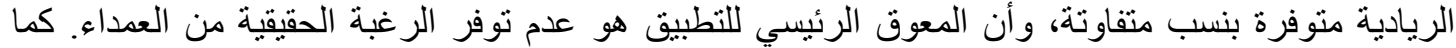

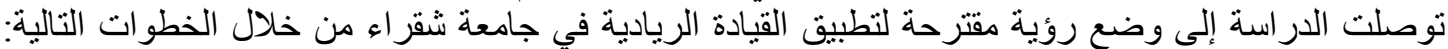

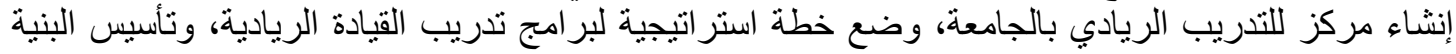
التحتية، ومتابعة تفعيل البرنامج في البيئة الجادئة البامعية.

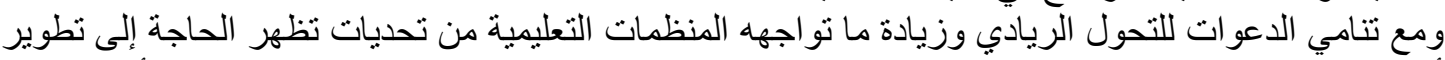

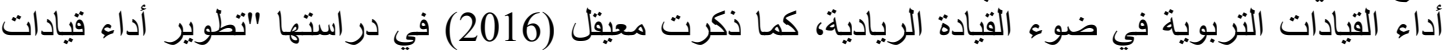

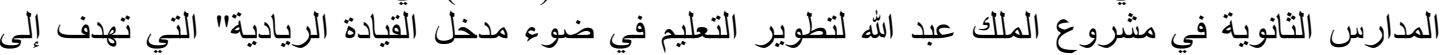

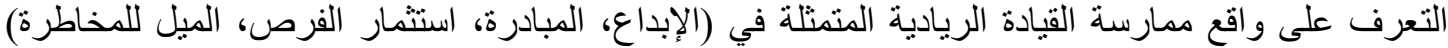

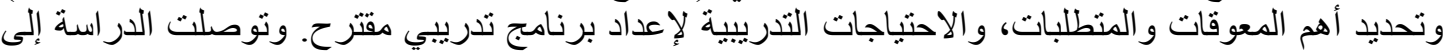

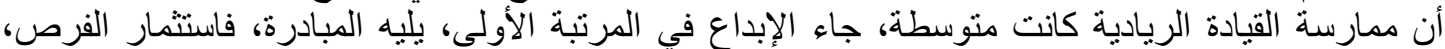

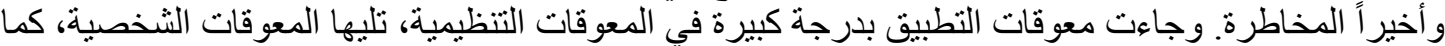

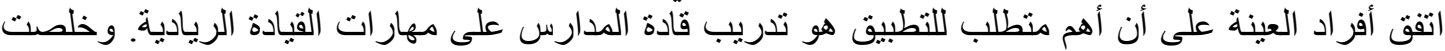

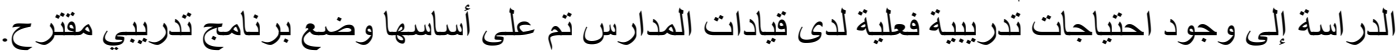

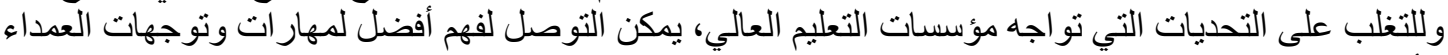

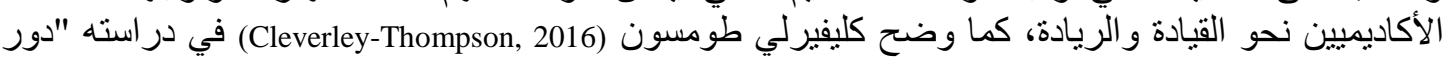


مبلحت (لفنون والأدب وتلوه الإنسانيات والبنتهماع Journal of Arts, Literature, Humanities and Social Sciences

ISSN online: 2414 - 3383

ISSN print: 2616 - 3810

العدد (4O) تموز - يوليو 2019

العمداء الأكاديمبين كقادة رياديين في مؤسسات التعليم العالي" التي كثفت عن وجود تر ابط كبير بين التوجهات

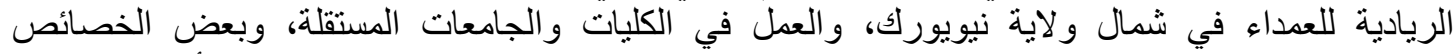

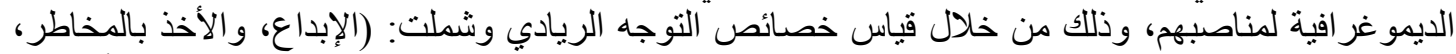

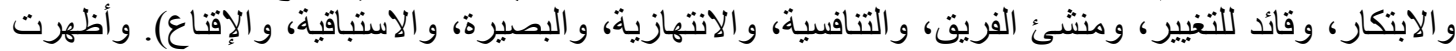

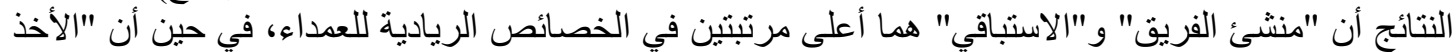

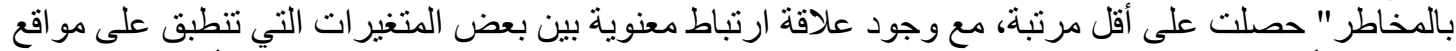

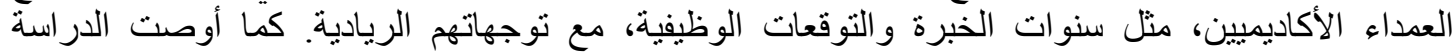

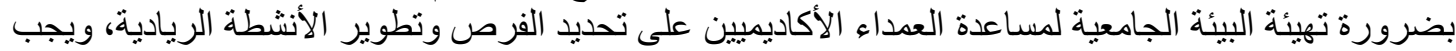

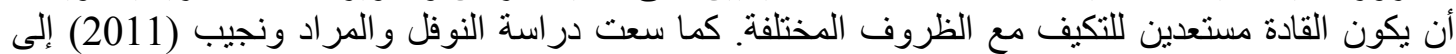

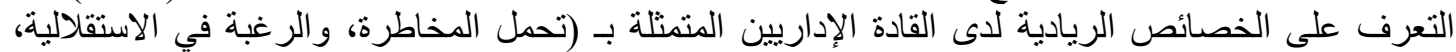

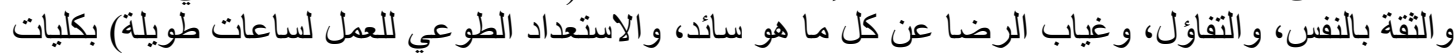

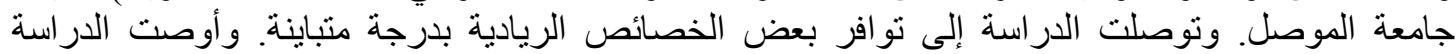

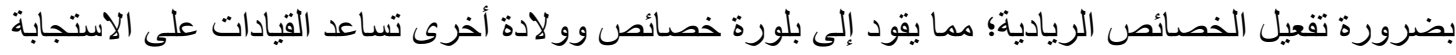

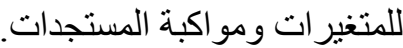

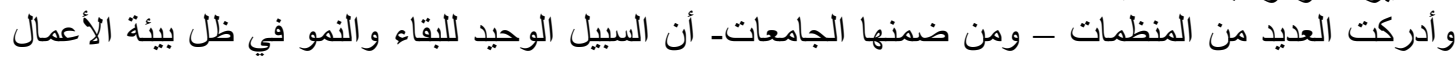
الجديدة هو تحقيق الريادة الاستر اتيجية؛ لذا تحتم على المنظمات تبني متطلبات الريات الريادة الاستر اتيجية و الخصائص الريادية، وذللك ما تطرقت له دراسة شمس الدين وطه وخضر (2016) التي هدفت إلى التى التعرف على التى تأثير الخصائص الريادية المتمثلة بـ (الخصائص الثخصية و السلوكية والإدارية) في متطلبات الريادة الإستر اتيجية

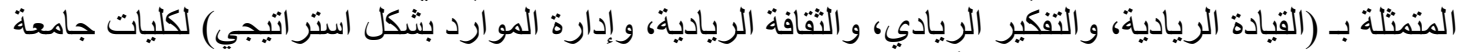

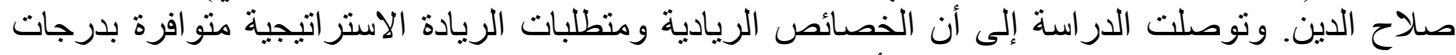
متفاوتة، مع وجود علاقة ارتباط معنوية وتأثنير معنوي للخصائص الريادية في متطلبات الريادة الإستر اتيجية.

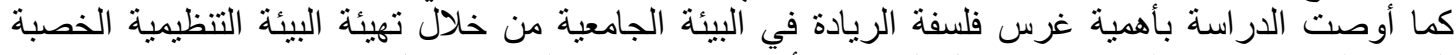
الداعمة للإبداع وتبني المخاطرة وتمويل المعرفة الأكاديمية واستثمار الفرص فئسية بشكل استباقي.

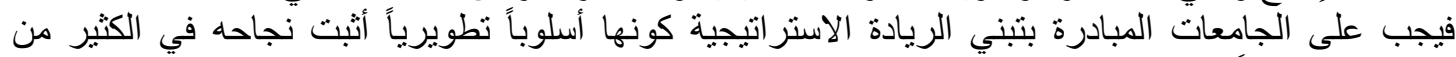

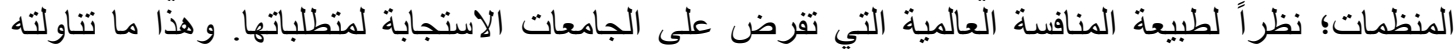

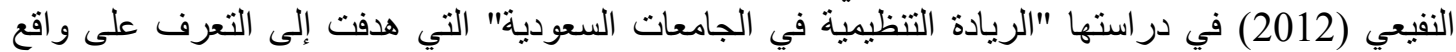

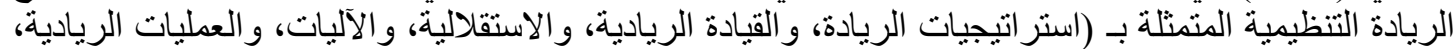

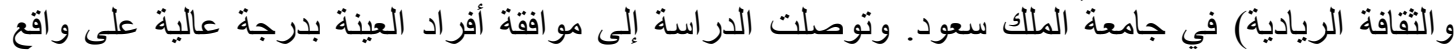

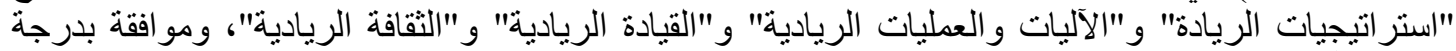

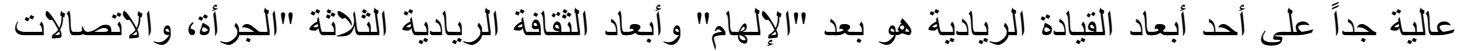
المفتوحة و التعاون"، أما و اقع "الاستقلالية" فيشير إلى انقسام في الآر اء تجاه بُعد "استقلادلية الوحدات الرات الجامعية".

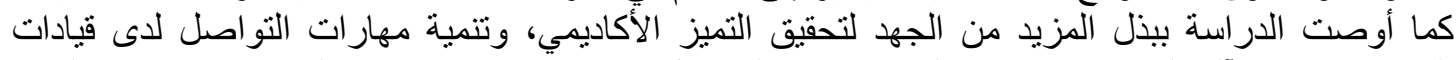
الجامعة، وإيجاد آلية لرصد احتياجات المستفيدين، و التواصل معهم وسرعة الاستجابة لهم، ومن ثم نشر الثقافة الريادية في جميع أنحاء الجامعة. ويبقى السؤال: كيف يمكن للجامعة أن تأخذ مفهوم الجامعة الريادية وتتفيذها عملياً؟ وما التحديات التي ستو اجه اجهاء

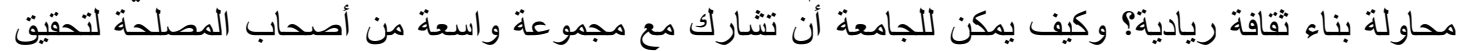

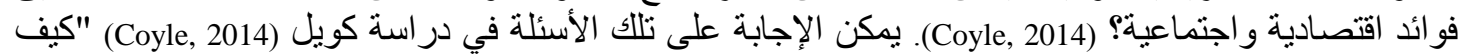
يمكن للقيادة الريادية إثراك موظفي الجامعة في تطوير التقافة الريادية" التي سعت إلى تحقيق الهدف الاستراتيجي لجامعة ويلز البريطانية لتصبح جامعة ريادية، من خلال تحديد مجموعة من السمات الرئ الريادية

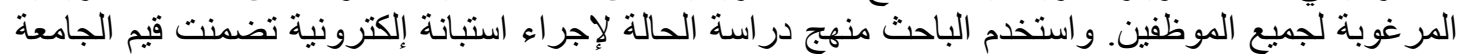

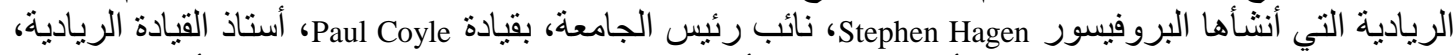
وتم توزيعها على جميع المنسوبين. وأظهرت النتائج أربع سمات ريادية متفق عليها في جميع أنحاء الجامعة: 
مبلحت (لفنون والأدب وعلوه الإنسانيات والهبانهماع Journal of Arts, Literature, Humanities and Social Sciences

ISSN online: 2414 - 3383

ISSN print: 2616 - 3810

العدد (4O) تموز - يوليو 2019

المهنية، و الثغف، و الثر اكة، و الاستحقاقية، كما ر افق كل سمة ثلاثة أوصاف قصيرة تشرح كيف يمكن إظهار ها الإنا

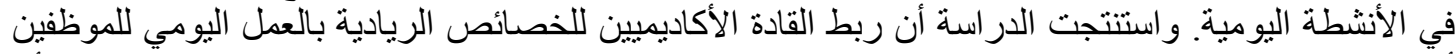

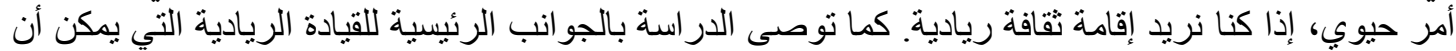
تدعم التفاعل بين الجامعات و الصناعة نداعة

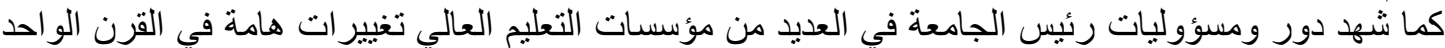

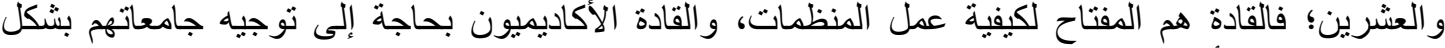

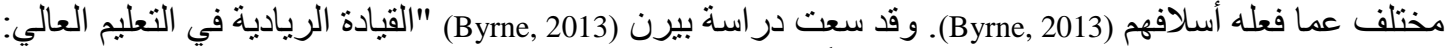

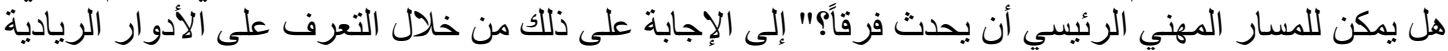

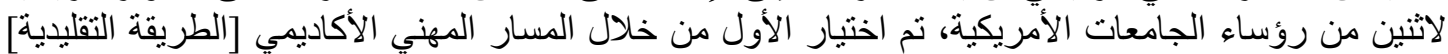

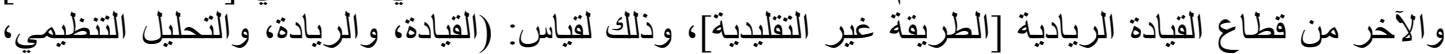

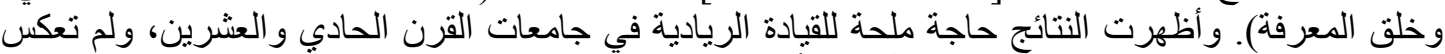

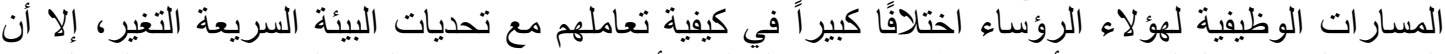

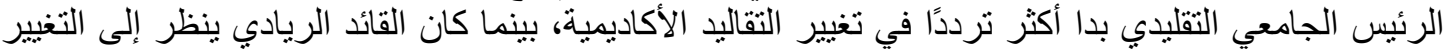

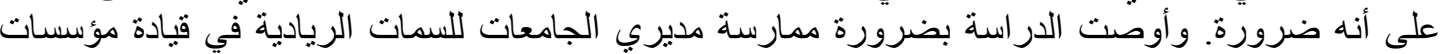

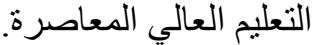
من خلال مال سبق تحاول هذه الدراسة تناول موضوع و اقع أبعاد القيادة الريادية في جامعة الإمام عبد الرحمن بن فيصل.

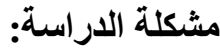
أطلقت المملكة العربية السعودية رؤية 2030 و التي تنص على الى ضرورة التوجه الريادي للجامعات، من خلال

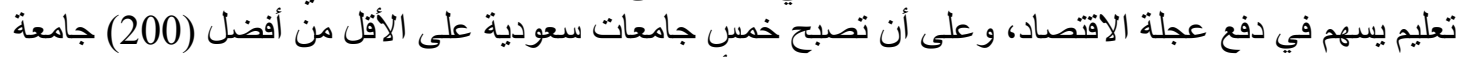

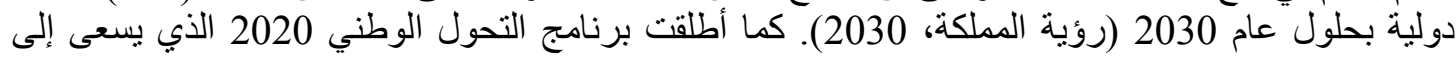

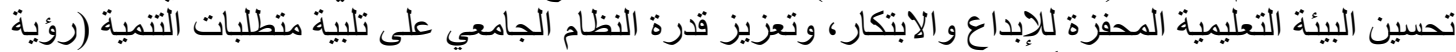

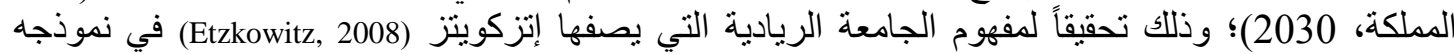

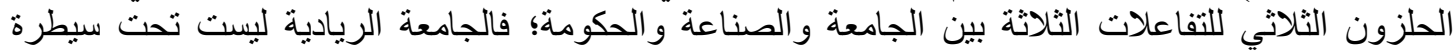

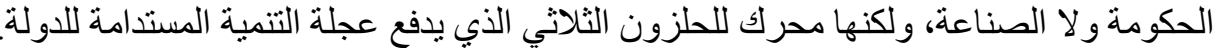

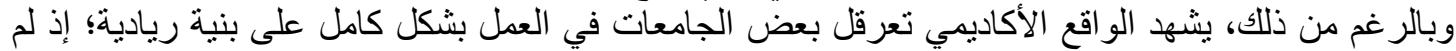

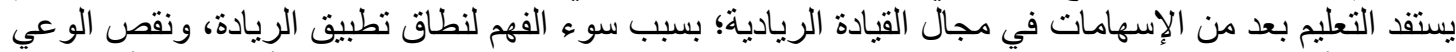

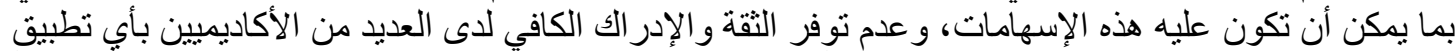

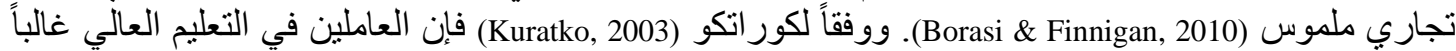

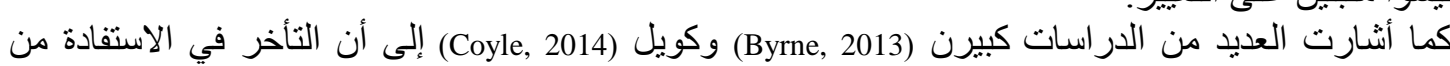

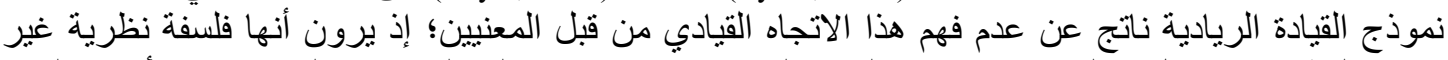

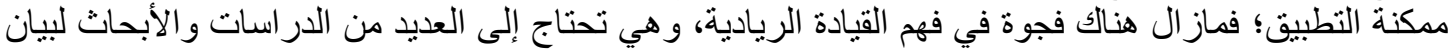

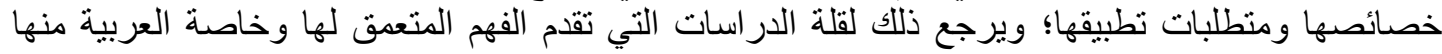
(القحطاني، 2015).

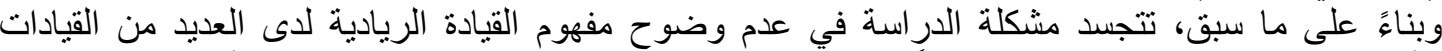

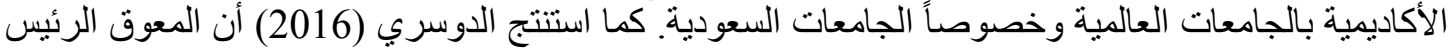

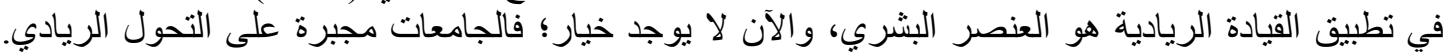

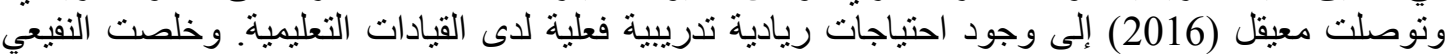

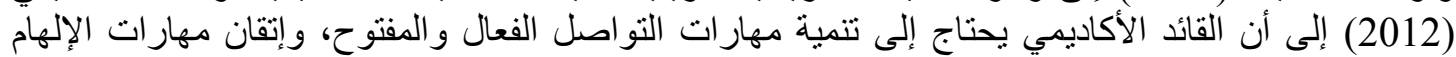

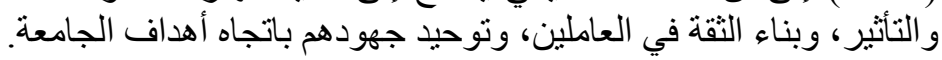




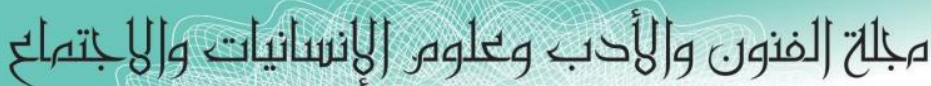

Journal of Arts, Literature, Humanities and Social Sciences

ISSN online: 2414 - 3383

ISSN print: 2616 - 3810

العدد (4O) تموز - يوليو 2019

وتتلخص مشكلة الدراسة في التعرف على مدى توافر أبعاد القيادة الريادية في جامعة الإمام عبد الرحمن بن فيصل بالمملكة العربية السعودية، وذللك من خلال درل در اسة القيادات الأكاديمية فيها.

أهداف الار استة: - مداف هدفت الدر اسة إلى تحقيق الهدفين التالينين:

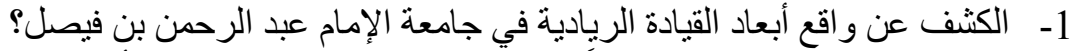

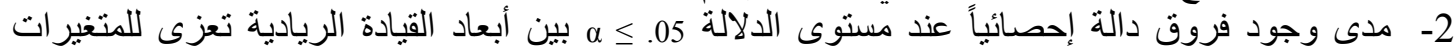
الديمو غر افية: الجنس، و الموقع الإداري، و والمرتبة المرية العلمية، وسنو ات الخدمة. أسئلة الار استة: سعت هذه الدر اسة إلى الإجابة عن السؤ الين التاليين:

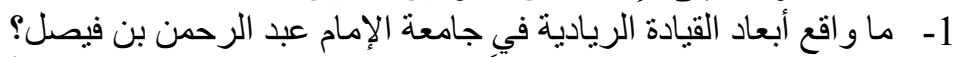

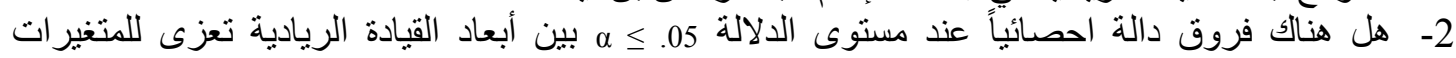

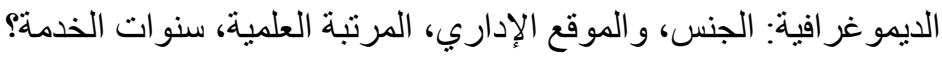

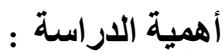

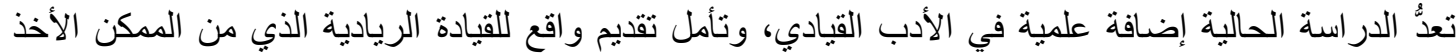

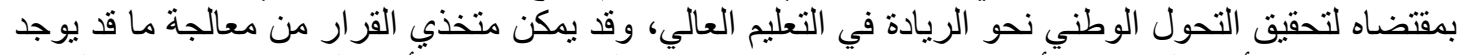
من قصور في أداء القيادات الأكاديمية، و الإسهام في إحداث نقلة نوعية في الأداء الجامعي بما يحقق الرئ الريادة و التفرد محلياً و عالمياً.

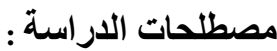

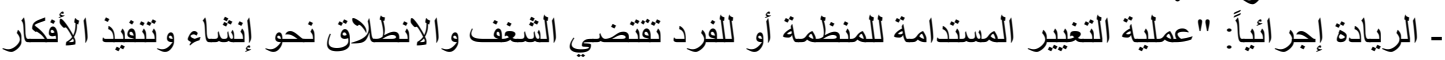

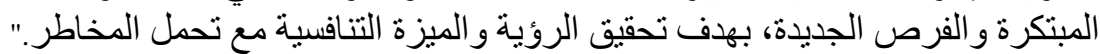

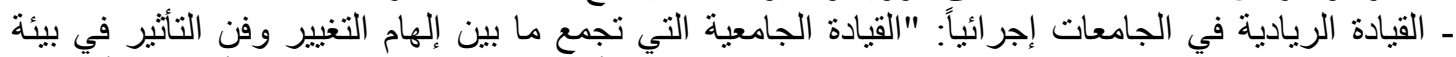

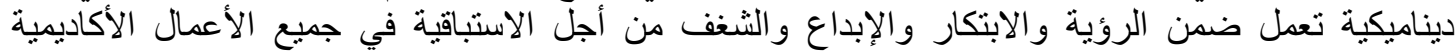

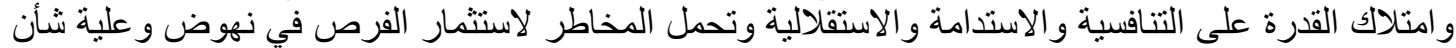

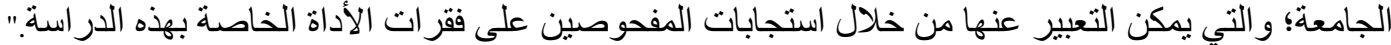

أبعاد القيادة الريادية إجرائيا: Entrepreneurial Leadership Dimensions

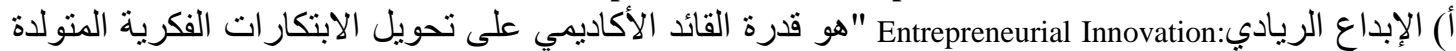

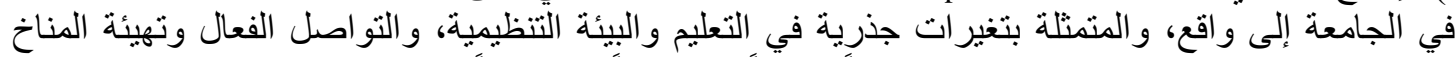

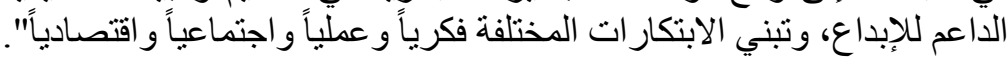

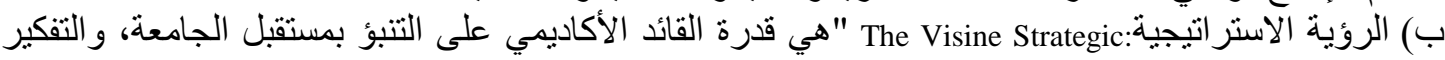

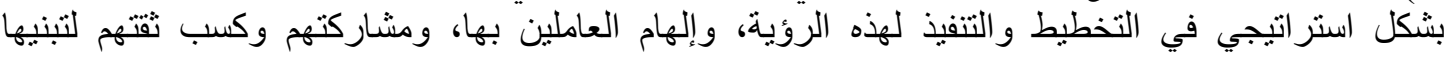
وتنفيذها". ج) الاستباقية:Proactiveness "هي قدرة القائد الريادي على تمكين الجامعة من سبق الجامعات الأخرى بميزتها

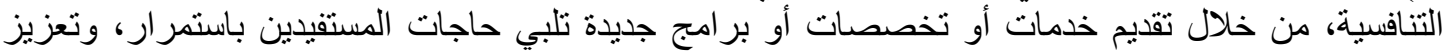

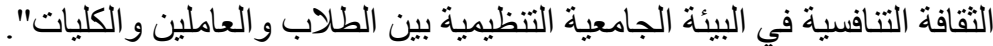

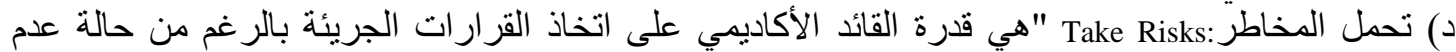
التأكد، مع توظيف القيادة الذاتية التي تمكنه من إدارة المخاطر بشكل استر اتيجي فعال، في سبيل تحقيق الأهداف التئ

الاستر اتيجية وتطور الجامعة". 


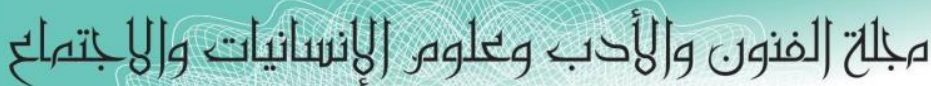

Journal of Arts, Literature, Humanities and Social Sciences

ISSN online: 2414 - 3383

ISSN print: 2616 - 3810

\section{العدد (4O) توز - يوليو 2019}

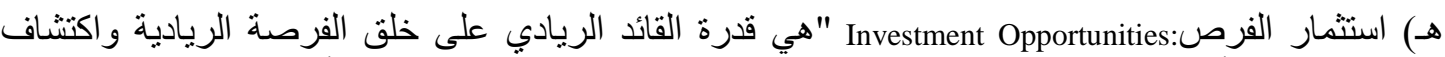

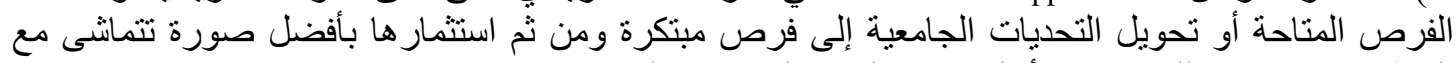

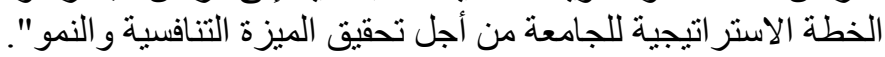
منهجية الار اسة وإجراءاتها: استخدمت الدر اسة المنهج الوصفي (المسحي)؛ وذللك لملاءمته لموضو عها و أهدافها.

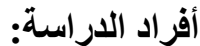

تألف أفر اد الدراسة من جميع القيادات الأكاديمية بجامعة الإمام عبد الرحمن بن فيصل و البالغ عددهم (177)

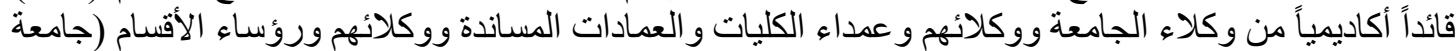

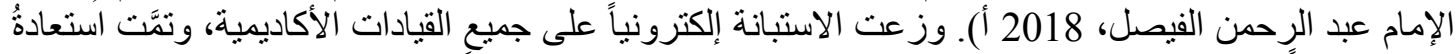

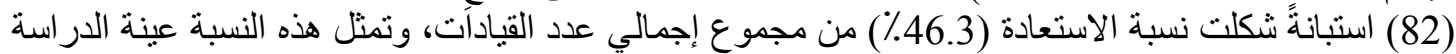
التي خضعت للتحليل الإحصائي. المتغيرات الايموغرافية لأفراد الداراسة:

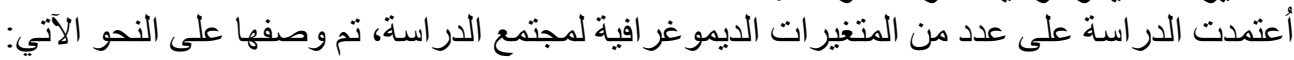
جدول (1): توزيع عينة الاراسة وفقاً لمتغير "الجنس"

\begin{tabular}{|c|c|c|}
\hline النسبة ٪ & التكرار & الجنس \\
\hline 51.2 & 42 & ذكر \\
\hline 48.8 & 40 & أنثى \\
\hline 100.0 & 82 & المجموع \\
\hline
\end{tabular}

يظهر الجدول (1) أن نسبة (51.2\%) من أفراد العينة ذكور، ونسبة (48.8\%) من الإناث.

جدول (2): توزيع عينة الاراسة وفقاً لمتغير "الموقع الإداري"

\begin{tabular}{|c|c|c|}
\hline النببة \% & التكرار & الموقع الاداري \\
\hline 4.9 & 4 & وكيل الجامعة \\
\hline 11.0 & 9 & عميد كلية \\
\hline 6.1 & 5 & عميد عمادة \\
\hline 32.9 & 27 & وكيل كلية \\
\hline 39.0 & 32 & رئيس قسم \\
\hline 6.1 & 5 & أخرى (مستشارون أكاديميون) \\
\hline 100.0 & 82 & 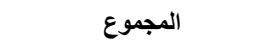 \\
\hline
\end{tabular}

يظهر الجدول (2) أن نسبة (39.0٪) من أفراد العينة "رؤساء أقسام"، ونسبة (32.9٪) "وكلاء كليات"، ونسبة

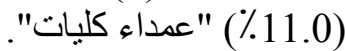




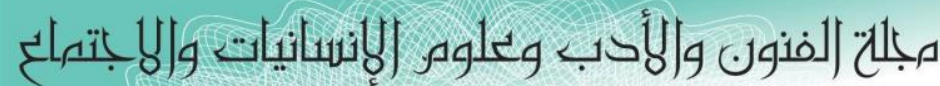

Journal of Arts, Literature, Humanities and Social Sciences

ISSN online: 2414 - 3383

ISSN print: 2616 - 3810

العدد (4O) تموز - يوليو 2019

\begin{tabular}{|c|c|c|}
\hline النسبة \% & التكرار & المرتبة العلمية \\
\hline 17.1 & 14 & أستاذ \\
\hline 19.5 & 16 & أستاذ مشارك \\
\hline 63.4 & 52 & أستاذ مساعد \\
\hline 100.0 & 82 & المجموع \\
\hline
\end{tabular}

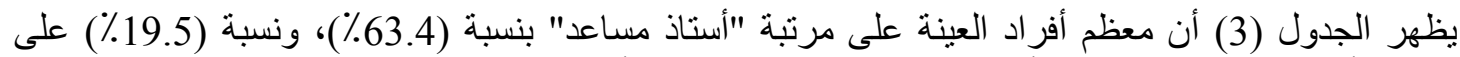
مرتبة "أستاذ مشارك"، في حين أن نسبة (17.1\%) على مرنبة "أستاذ".

جدول (4): توزيع عينة الدراسة وفقاً لسنوات الخدمة

\begin{tabular}{|c|c|c|}
\hline النسبة \% & التكرار & سنوات الخذمة \\
\hline 17.1 & 14 & أقل من 5 سنو ات \\
\hline 19.5 & 16 & من 5- 10 سنوات \\
\hline 63.4 & 52 & أكثر من 10 سنوات \\
\hline 100.0 & 82 & المجموع \\
\hline
\end{tabular}

يظهر الجدول (4) أن معظم أفر اد العينة خدمتهم "أكثر من 10 سنوات" بنسبة (63.4\%)، ونسبة (19.5\%) لديهم

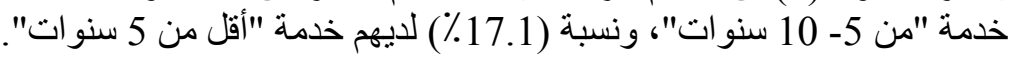

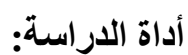

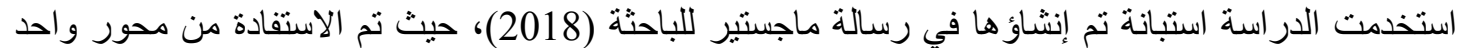

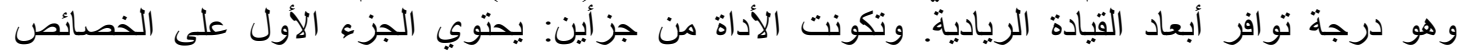

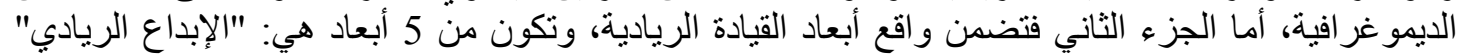

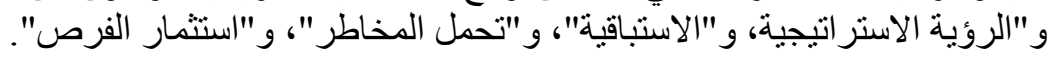

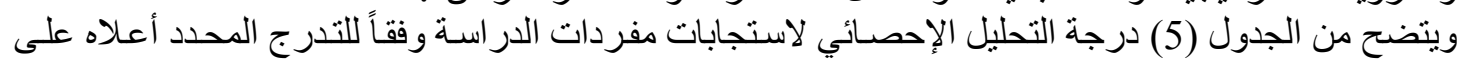

جدول (5): فئات مقياس استجابات مفردات الدراسة

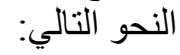

\begin{tabular}{|c|c|c|c|}
\hline \multicolumn{4}{|c|}{ الدلالة اللفظية } \\
\hline عالية & متوسطة & ضعيفة & منعدمة \\
\hline $3.264-$ & $2.51-3.25$ & $1.76-2.50$ & $1-1.75$ \\
\hline
\end{tabular}

صدق وثبات أداة الدراسة:

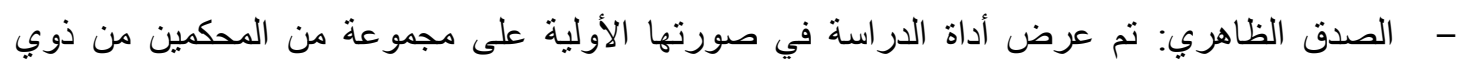
الاختصاص في الإدارة و الريادة التربوية بلغ عددهم ستة محكمين؛ وذلك لقياس ما وُضِعِ لقياسها، ومدى كفاية 
مبلحت (لفنون والأدب وتلوه الإنسانيات والبانتهاع Journal of Arts, Literature, Humanities and Social Sciences

ISSN online: 2414 - 3383

ISSN print: 2616 - 3810

\section{العدد (4O) تموز - يوليو 2019}

الفقر ات لتغطية كل بعد من أبعاد الدراسة. وفي ضوء التوجيهات التي أبداها المحكمون نم التعديل بما ينسجم مع

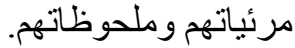

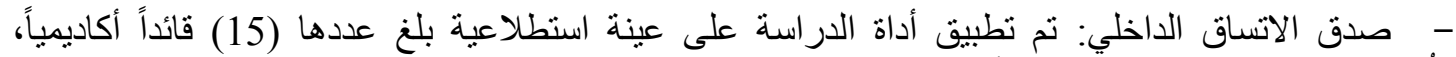

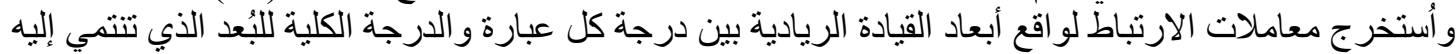

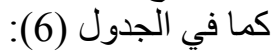

جدول رقم (6): معاملات ارتباط بيرسون بين العبارة والبعد الأي تنتمي إليه لواقع أبعاد القيادة الريادية

\begin{tabular}{|c|c|c|c|c|c|c|c|c|c|}
\hline معامل الارتباط & الفقرة & معامل الارتباط & الفقرة & معامل الارتباط & الفقرة & معامل الارتباط & الفقرة & الارتباط & الفقرة \\
\hline \multicolumn{2}{|c|}{ البُعد الخامس } & \multicolumn{2}{|c|}{ البُجّد الرابع } & \multicolumn{2}{|c|}{ البُعد الثالث } & \multicolumn{2}{|c|}{ البُعد الثُاني } & \multicolumn{2}{|c|}{ البُعْد الأول } \\
\hline$* * 0.86$ & 1 & $* * 0.87$ & 1 & $* * 0.79$ & 1 & $* * 0.74$ & 1 & $* * 0.68$ & 1 \\
\hline$* * 0.84$ & 2 & $* * 0.83$ & 2 & $* * 0.81$ & 2 & $* * 0.80$ & 2 & $* * 0.75$ & 2 \\
\hline$* * 0.90$ & 3 & $* * 0.74$ & 3 & $* * 0.78$ & 3 & $* * 0.72$ & 3 & $* * 0.78$ & 3 \\
\hline$* * 0.76$ & 4 & $* * 0.78$ & 4 & $* * 0.78$ & 4 & $* * 0.80$ & 4 & $* * 0.72$ & 4 \\
\hline \multirow[t]{6}{*}{$* * 0.83$} & 5 & $* * 0.80$ & 5 & **0.78 & 5 & $* * 0.82$ & 5 & $* * 0.77$ & 5 \\
\hline & & $* * 0.82$ & 6 & $* * 0.81$ & 6 & $* * 0.77$ & 6 & $* * 0.80$ & 6 \\
\hline & & $* * 0.87$ & 7 & & & $* * 0.85$ & 7 & $* * 0.77$ & 7 \\
\hline & & & & & & $* * 0.80$ & 8 & $* * 0.65$ & 8 \\
\hline & & & & & & $* * 0.77$ & 9 & $* * 0.86$ & 9 \\
\hline & & & & & & $* * 0.87$ & 10 & $* * 0.69$ & 10 \\
\hline
\end{tabular}

يوضح الجدول (6) وجود علاقة ارتباط موجبة ومصداقية مرتفعة لبناء أداة الدر اسة عند مستوى الدلالة (0.01).

- ثبات أداة الدراسة: تم حساب معامل ألفا كرونباخ للتبات و أظهرت النتيجة ثباتاً مرتفعاً كما يظهر في الجدول

جدول (7): معامل " ألفا كرونباخ" لواقع أبعاد القيادة الريادية

\begin{tabular}{|c|c|c|}
\hline معامل الثبات & عدد الفقر ات & البُعد \\
\hline 0.91 & 10 & البُعد الأول \\
\hline 0.93 & 10 & البُعد الثاني \\
\hline 0.90 & 6 & البُعد الثالث \\
\hline 0.89 & 7 & البُّد الرابع \\
\hline 0.86 & 5 & البُعد الخامس \\
\hline 0.97 & 38 & الاستبانة \\
\hline
\end{tabular}

اساليب المعالجة الإحصائية:

ولتحليل بيانات الدراسة تم الإحصائة الاعتماد على برنامج الرُزم الإحصائية (Statistical Package for Social Sciences)

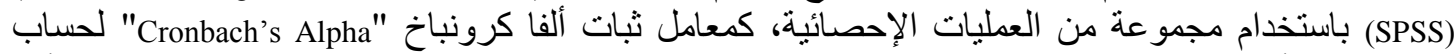
معامل ثبات أداة الدر اسة، ومعامل ارتباط بيرسون "Pearson Correlation" لحساب صدق من الاتساق الداخلي لألأداة

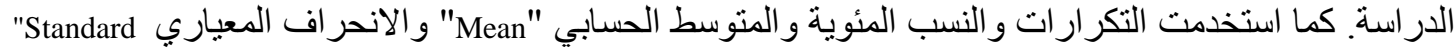

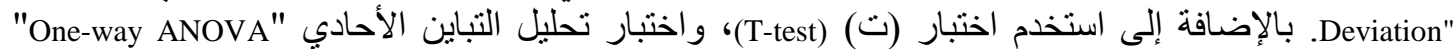
لتحديد الفروق بين استجابات أفر اد الدر اسة. 


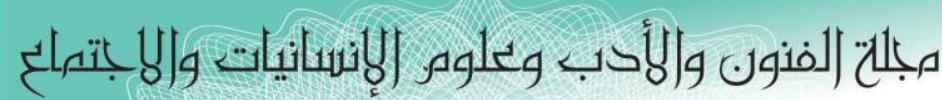

Journal of Arts, Literature, Humanities and Social Sciences

ISSN online: 2414 - 3383

ISSN print: 2616 - 3810

\section{العدد (4O) تموز - يوليو 2019}

عرض نتائج الاراسة وتحليلها: الإجابة على السؤال الأول: ما واقع أبعاد القيادة الريادية بجامعة الإمام عبد الرحمن بن فيصل؟

جدول (8): المتوسطات الحسابية والانحرافات المعيارية لواقع أبعاد القيادة الريادية

\begin{tabular}{|c|c|c|c|c|c|}
\hline 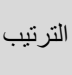 & 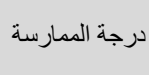 & المعياري & المتوسط الحسابي & الأبعد & 5 \\
\hline 2 & متوسطة & 0.56 & 3.20 & الإبداع الريادي (للجامعة و القائد الأكاديمي) & 1 \\
\hline 1 & منوسطة & 0.61 & 3.23 & الروية الاستر اتيجية (للجامعة وللقائد الأكاديمي) & 2 \\
\hline 3 & منوسطة & 0.68 & 3.15 & 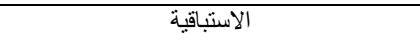 & 3 \\
\hline 5 & منوسطة & 0.67 & 3.02 & تحمل المخاطر من قبل القائد الأكاديمي & 4 \\
\hline 4 & منوسطة & 0.65 & 3.08 & استثمار الفرص للقائد الأكاديمي & 5 \\
\hline \multicolumn{2}{|c|}{ منوسطة } & 0.57 & 3.15 & \multicolumn{2}{|l|}{ و اقع أبعاد القيادة الريادية } \\
\hline
\end{tabular}

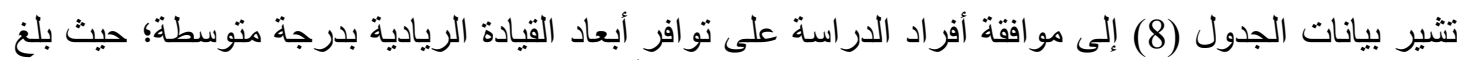

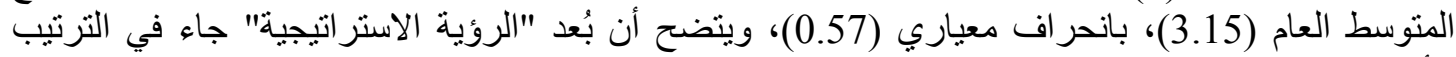

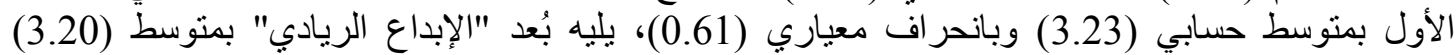

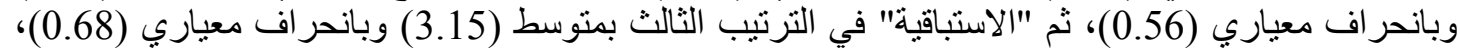

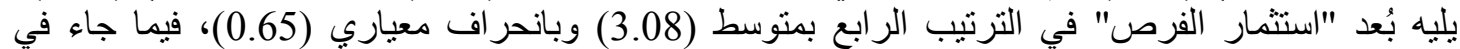

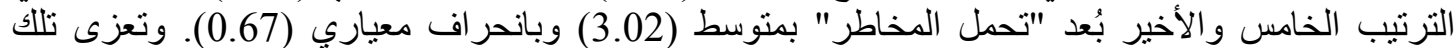

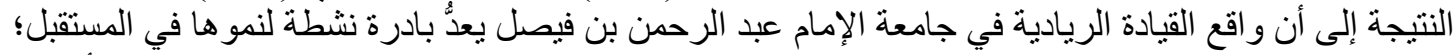

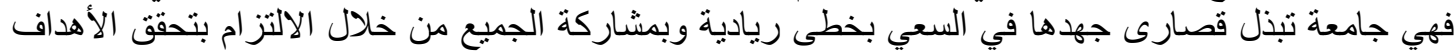

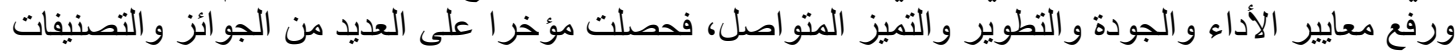

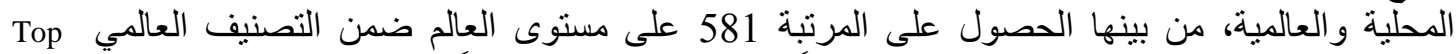
University QS

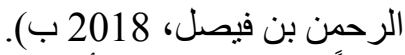

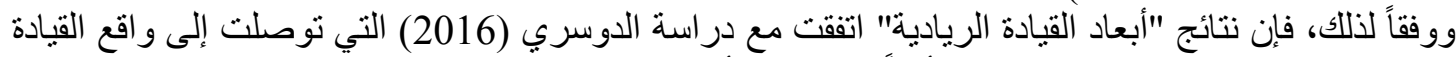

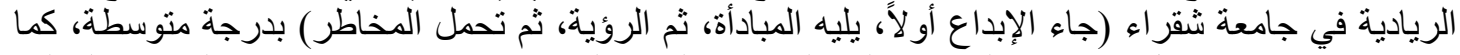

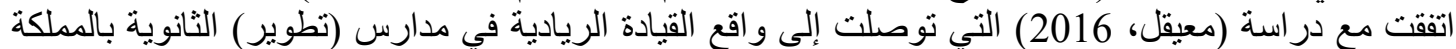

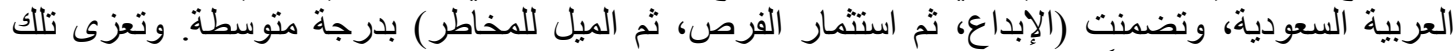

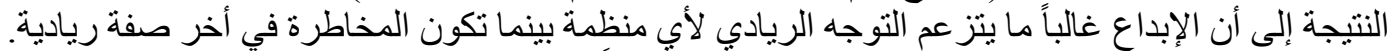

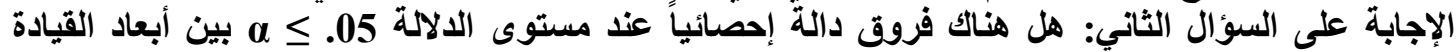

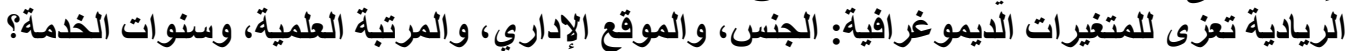

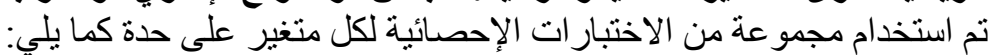

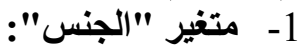
تم استخدام اختبار (ت) (Independent Samples T-test) لبيان الفروق بين استجابات أفر اد العينة لمتغير "الجنس"، و النتيجة كما هي مبينة في الجدول (9): (ت) 


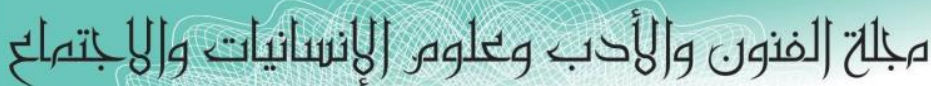

Journal of Arts, Literature, Humanities and Social Sciences

ISSN online: 2414 - 3383

ISSN print: 2616 - 3810

العدد (4O) تموز - يوليو 2019

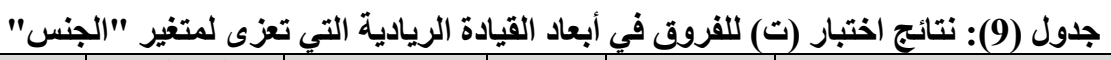

\begin{tabular}{|c|c|c|c|c|c|c|}
\hline الدلالة & قيمة (ت) & الالحياري اف & المتوسط الحسابي & العدد & الجنس & 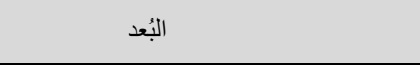 \\
\hline \multirow{2}{*}{0.627} & \multirow{2}{*}{0.49} & 0.51 & 3.17 & 42 & ذكر & \multirow{2}{*}{ الإبداع الريادي (للجامعة و القائد الأكاديمي) } \\
\hline & & 0.62 & 3.23 & 40 & أنثى & \\
\hline \multirow{2}{*}{0.135} & \multirow{2}{*}{1.51} & 0.61 & 3.14 & 42 & ذكر & \multirow{2}{*}{ الرؤية الاستر اتيجية (للجامعة و القائد الأكاديمي) } \\
\hline & & 0.60 & 3.34 & 40 & أنثى & \\
\hline \multirow{2}{*}{0.549} & \multirow{2}{*}{0.60} & 0.61 & 3.19 & 42 & ذكر & \multirow{2}{*}{ الاستباقية } \\
\hline & & 0.74 & 3.10 & 40 & أنثى & \\
\hline \multirow{2}{*}{0.723} & \multirow{2}{*}{0.36} & 0.64 & 2.99 & 42 & ذكر & \multirow{2}{*}{ تحمل المخاطر من قبل القائد الأكاديمي } \\
\hline & & 0.71 & 3.05 & 40 & أنثى & \\
\hline \multirow{2}{*}{0.620} & \multirow{2}{*}{0.50} & 0.60 & 3.05 & 42 & ذكر & \multirow{2}{*}{ استثمار الفرص للقائد الأكاديمي } \\
\hline & & 0.71 & 3.12 & 40 & أنثى & \\
\hline \multirow{2}{*}{0.562} & \multirow{2}{*}{0.58} & 0.53 & 3.12 & 42 & ذكر & \multirow{2}{*}{ أبعاد القيادة الريادية } \\
\hline & & 0.62 & 3.19 & 40 & أنثى & \\
\hline
\end{tabular}

يظهر الجدول (9) عدم وجود فروق ذات دلالة إحصائية في أبعاد القيادة الريادية تعزى لمتغير "الجنس".

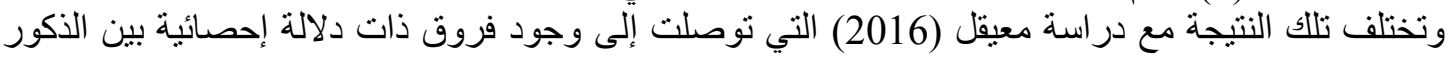

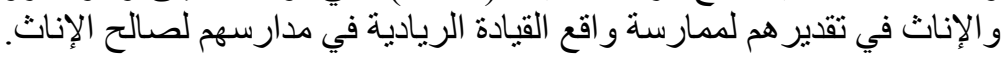

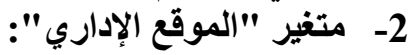

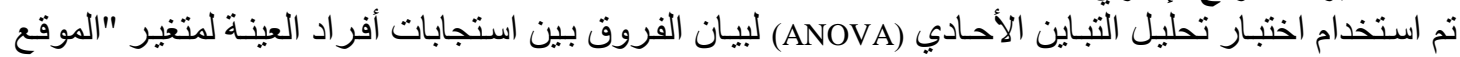

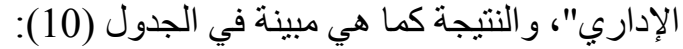
جدول (10): تحليل التباين الأحادي للفروق في أبعاد القيادة الريادية التي تعزى لمتغير "الموقع الإداري"

\begin{tabular}{|c|c|c|c|c|c|c|}
\hline الدلالة & قيمة (ف) & المربعات & درجة الحرية & المربعوع & مصدر التباين & المحور \\
\hline \multirow{2}{*}{0.11} & \multirow{2}{*}{2.24} & 0.69 & 2 & 1.39 & بين المجمو عات & \multirow{2}{*}{ 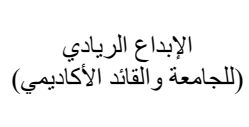 } \\
\hline & & 0.31 & 79 & 24.44 & داخل المجمو عات & \\
\hline \multirow{2}{*}{0.34} & \multirow{2}{*}{1.10} & 0.41 & 2 & 0.82 & بين المجمو عات & \multirow{2}{*}{ 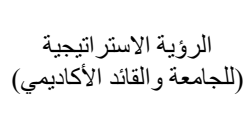 } \\
\hline & & 0.37 & 79 & 29.29 & داخل المجمو عات & \\
\hline \multirow{2}{*}{0.21} & \multirow{2}{*}{1.57} & 0.71 & 2 & 1.42 & بين المجموعات & \multirow{2}{*}{ الاستباقية } \\
\hline & & 0.45 & 79 & 35.62 & داخل المجمو عات & \\
\hline \multirow{2}{*}{0.24} & \multirow{2}{*}{1.45} & 0.65 & 2 & 1.30 & بين المجمو عات & \multirow{2}{*}{ من قبل القائد الأكاديمي } \\
\hline & & 0.45 & 79 & 35.51 & داخل المجمو عات & \\
\hline \multirow{2}{*}{0.69} & \multirow{2}{*}{0.37} & 0.16 & 2 & 0.32 & بين المجمو عات & \multirow{2}{*}{ اللقائد الأكاديمي الفرص } \\
\hline & & 0.44 & 79 & 34.39 & داخل المجمو عات & \\
\hline \multirow{2}{*}{0.21} & \multirow{2}{*}{1.57} & 0.51 & 2 & 1.02 & بين المجموعات & \multirow{2}{*}{ أبعاد القيادة الريادية } \\
\hline & & 0.33 & 79 & 25.71 & داخل المجمو عات & \\
\hline
\end{tabular}

عند مستوى الدلالة 05. 


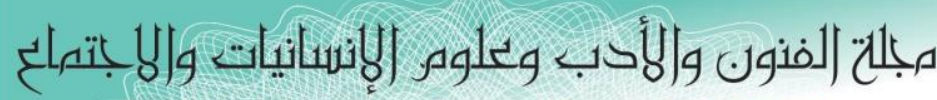
Journal of Arts, Literature, Humanities and Social Sciences

ISSN online: 2414 - 3383

ISSN print: 2616 - 3810

\section{العدد (4O) توز - يوليو 2019}

يظهر الجدول (10) عدم وجود فروق ذات دلالة إحصائية في أبعاد القيادة الريادية لجميع الأبعاد تعزى لمتغير

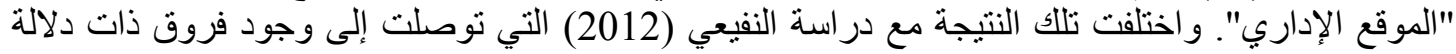

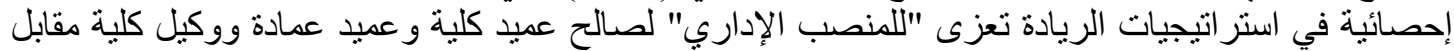
وكيلة قسم بجامعة الملك سعود.

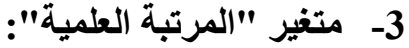

تم استخدام اختبار تحليل التباين الأحادي (ANOVA) لبيان الفروق بين استجابات أفراد العينة لـتغير "المرتبة العلمية"، و النتيجة كما هي مبينة في الجدول (11):

جدول (11): تحليل التباين الأحادي للفروق في أبعاد القيادة الريادية التي تعزى لمتغير "المرتبة العلمية"

\begin{tabular}{|c|c|c|c|c|c|c|}
\hline 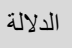 & قيمة (ف) & متوسط المربعات & درجة الحرية & مجموع المربعات & مصدر التباين & المحور \\
\hline \multirow{2}{*}{0.18} & \multirow{2}{*}{1.72} & 0.54 & 2 & 1.08 & بين المجمو عات & \multirow{2}{*}{ (للجامعة والقائد الأكاديمي) } \\
\hline & & 0.31 & 79 & 24.75 & داخل المجمو عات & \\
\hline \multirow{2}{*}{0.28} & \multirow{2}{*}{1.29} & 0.48 & 2 & 0.95 & بين المجموعات & \multirow{2}{*}{ (للجامعة و القائد الأكاديمي) } \\
\hline & & 0.37 & 79 & 29.15 & داخل المجمو عات & \\
\hline \multirow{2}{*}{0.16} & \multirow{2}{*}{1.85} & 0.83 & 2 & 1.66 & بين الدجمو عات & \multirow{2}{*}{ الاستباقية } \\
\hline & & 0.45 & 79 & 35.37 & داخل المجموعات & \\
\hline \multirow{2}{*}{0.59} & \multirow{2}{*}{0.54} & 0.25 & 2 & 0.49 & بين المجمو عات & \multirow{2}{*}{ من قبل القائد الأكاديمي } \\
\hline & & 0.46 & 79 & 36.31 & داخل المجمو عات & \\
\hline \multirow{2}{*}{0.61} & \multirow{2}{*}{0.50} & 0.22 & 2 & 0.43 & بين المجموعات & \multirow{2}{*}{ اللقائد الأكاديمي الفرص } \\
\hline & & 0.43 & 79 & 34.28 & داخل المجمو عات & \\
\hline \multirow{2}{*}{0.27} & \multirow{2}{*}{1.34} & 0.44 & 2 & 0.88 & بين المجمو عات & \multirow{2}{*}{ أبعاد القيادة الريادية } \\
\hline & & 0.33 & 79 & 25.85 & داخل المجمو عات & \\
\hline
\end{tabular}

عند مستوى الالالة

يظهر الجدول (11) عدم وجود فروق ذات دلالة إحصائية في أبعاد القيادة الريادية تعزى لمتغير "المرتبة

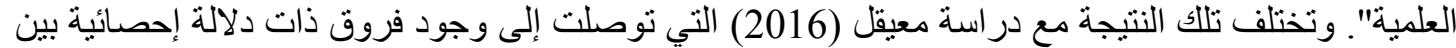

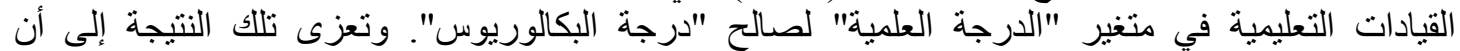

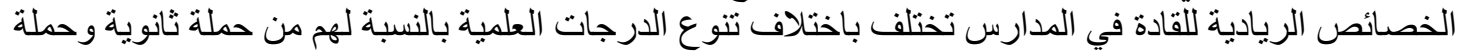

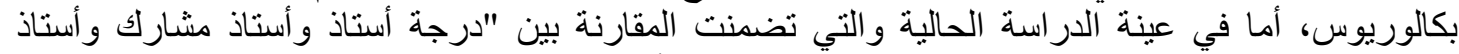

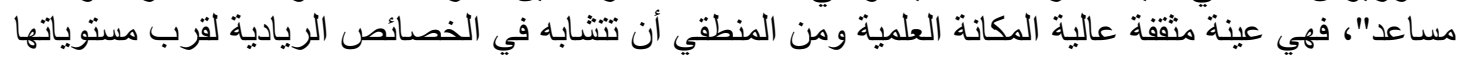




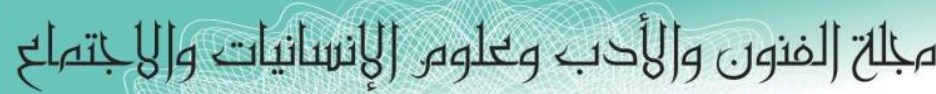
Journal of Arts, Literature, Humanities and Social Sciences

ISSN online: 2414 - 3383

ISSN print: 2616 - 3810

العدد (4O) تموز - يوليو 2019

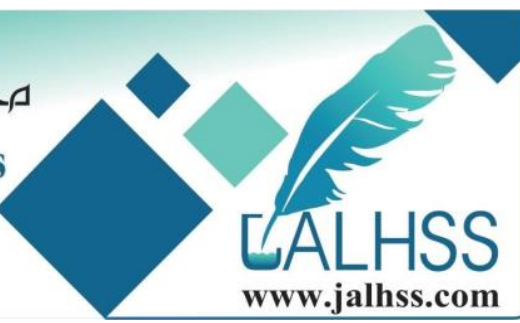

4- - متغير "سنوات الخدمة":

جدول (12): تحليل التباين الأحادي للقروق في أبعاد القيادة الريادية التي تعزى لمتغير "سنوات الخدمة"

\begin{tabular}{|c|c|c|c|c|c|c|}
\hline الدلالة & قيمة (ف) & متوسط المربعات & درجة الحرية & مجموع المربعات & مصدر التباين & المحور \\
\hline \multirow{2}{*}{0.45} & \multirow{2}{*}{0.80} & 0.26 & 2 & 0.51 & بين المجمو عات & \multirow{2}{*}{ (للجامعة والقائد الأكاديمي) } \\
\hline & & 0.32 & 79 & 25.32 & داخل المجمو عات & \\
\hline \multirow{2}{*}{0.68} & \multirow{2}{*}{0.38} & 0.14 & 2 & 0.29 & بين المجمو عات & \multirow{2}{*}{ 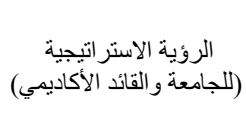 } \\
\hline & & 0.38 & 79 & 29.82 & داخل المجمو عات & \\
\hline \multirow{2}{*}{0.60} & \multirow{2}{*}{0.52} & 0.24 & 2 & 0.48 & بين المجمو عات & \multirow{2}{*}{ الاستباقية } \\
\hline & & 0.46 & 79 & 36.55 & داخل المجموعات & \\
\hline \multirow{2}{*}{0.86} & \multirow{2}{*}{0.15} & 0.07 & 2 & 0.14 & بين المجمو عات & \multirow{2}{*}{ من قبل القائد الأكاديمي } \\
\hline & & 0.46 & 79 & 36.67 & داخل المجمو عات & \\
\hline \multirow{2}{*}{0.43} & \multirow{2}{*}{0.86} & 0.37 & 2 & 0.74 & بين المجمو عات & \multirow{2}{*}{ اللقائد الأكاديمي الفرص } \\
\hline & & 0.43 & 79 & 33.98 & داخل المجمو عات & \\
\hline \multirow{2}{*}{0.78} & \multirow{2}{*}{0.25} & 0.08 & 2 & 0.17 & بين المجمو عات & \multirow{2}{*}{ أبعاد القيادة الريادية } \\
\hline & & 0.34 & 79 & 26.56 & داخل المجمو عات & \\
\hline
\end{tabular}

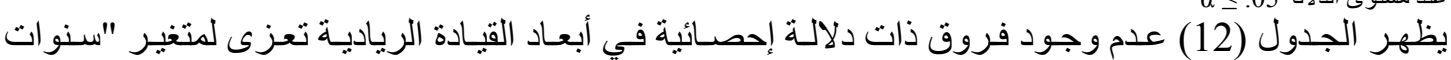

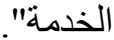
وتعزى نتائج عدم وجود فروق بين أبعاد القيادة الريادية وفقاً للمتغيرات السابقة (الجنس، و الموقع الإداري،

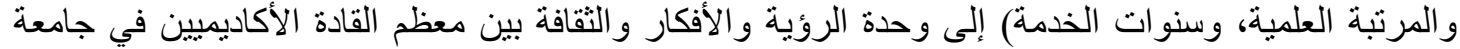

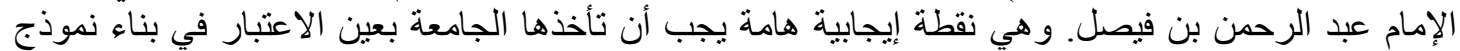
موحد لتطبيق القيادة الريادية بحسب مان ما تتطلع لله هذه القيادات.

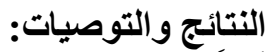

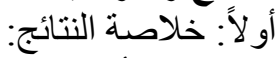

1. توفر أبعاد القبادة الريادية في جامعة الإمام عبد الرحمن بن فيصل بدرجة متوسطة؛ فقد جاء بُعد "الرؤية

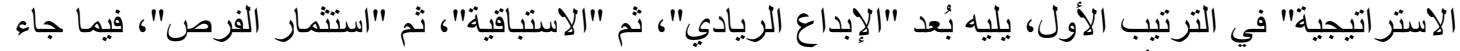

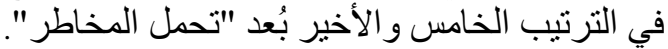
2. عدم وجود فروق ذات دلالة إحصائية بين أبعاد القيادة الريادية تعزى لمتغير "الجنس" و "الموقع الإداري"

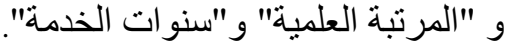




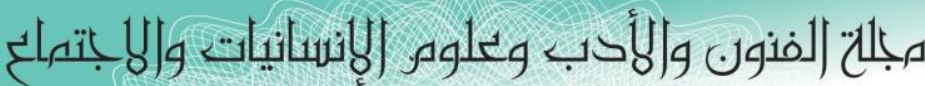

Journal of Arts, Literature, Humanities and Social Sciences

ISSN online: 2414 - 3383

ISSN print: 2616 - 3810

العدد (4O) توز - يوليو 2019

¿ALLHSS

www.jalhss.com

أكاديمية استطاعت الاستتات: جامعة الإمام عبد الرحمن بن فيصل أن تتخذ لنفسها هوية جامعية، ورؤية طموحة، وسمعة

- - تتجه جامعة الإمام عبد الرحمن بن فيصل لامتهان الابتكار وريادة الأعمال كوظيفة جديدة للجامعة الريادية

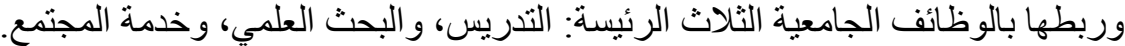

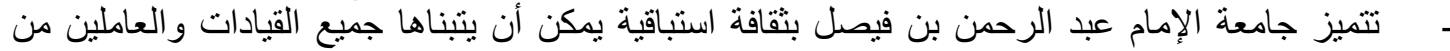
خلال العمل بمنطلبات القيادة الريادية.

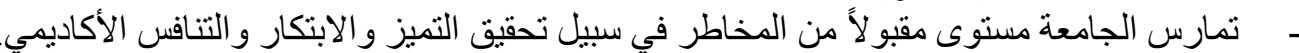
- - تستثمر الجامعة الفرص الريادية وتعدُها خارطة الطريق للريادة وتحقيق مر اكز متقدمة في التصنيفات الأكاديمية عالمياً و عربياً ومحلياً.

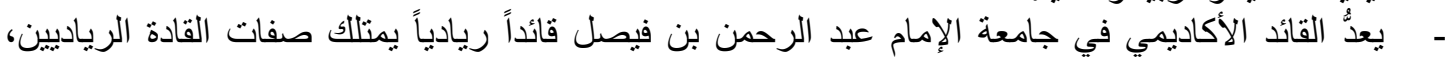

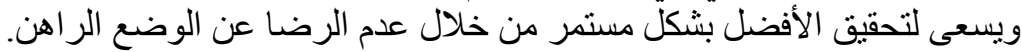

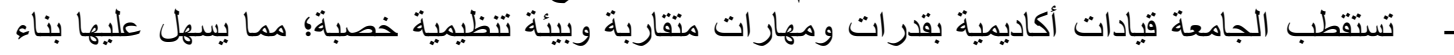
استر اتيجية خاصة لتطبيق القيادة الريادية.

ثانياً: التوصيات:

بناء على النتائج التي توصلت إليهات التهات هذه الدر اسة؛ توصي بالآتي:

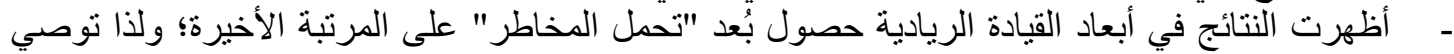
الدراسة بضرورة تبني بعد المخاطرة عند التفكير "بمشاريع ريادية" تسهم بنقل الجامعة من موضع استرانية اتيجي

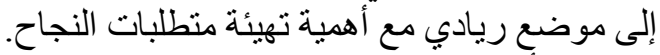

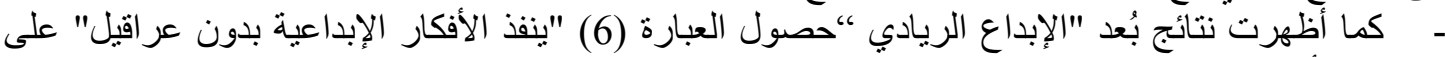
المرتبة الأخيرة؛ لذا توصى الدراسة بالنظر في معيقات تطبيق الإبداع الريادي في الجامعة و اكتشاف مسبباتها

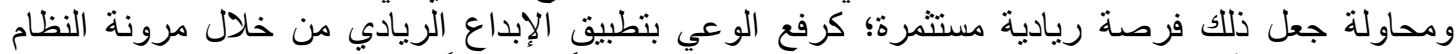

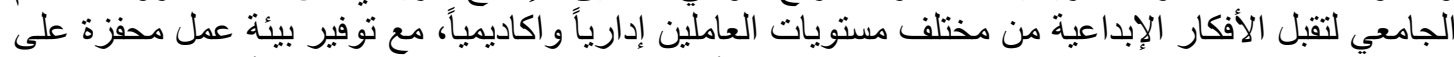

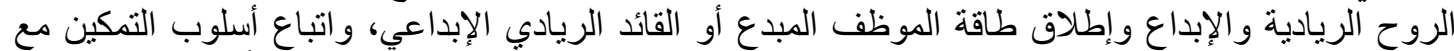

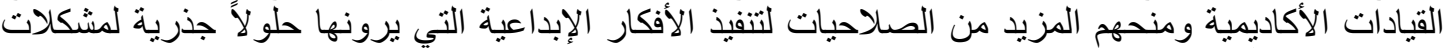

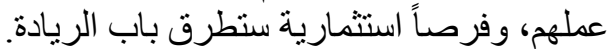

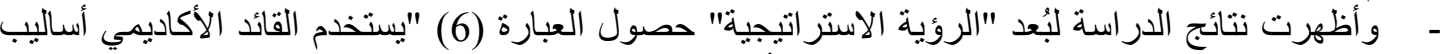

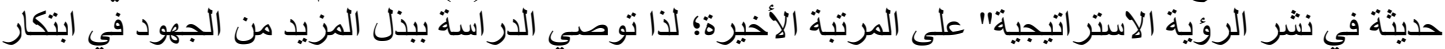
الأساليب و الطرق الإبداعية في نشر الرؤية الجامعية واللوائح التنفيذية حتى تحقق أهدافها في تعزيز الهوية

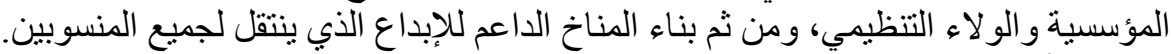

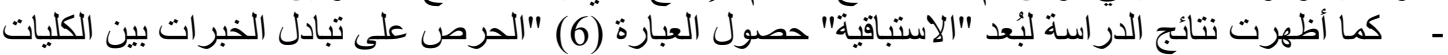

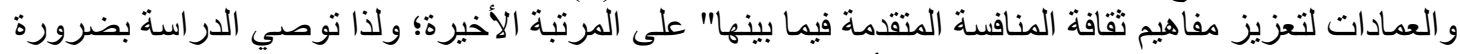

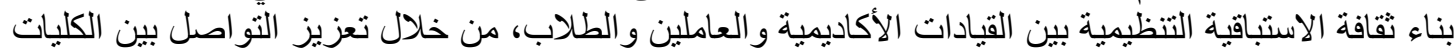

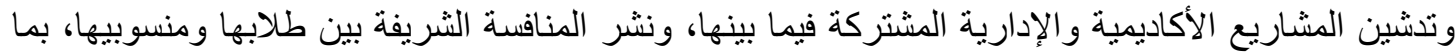

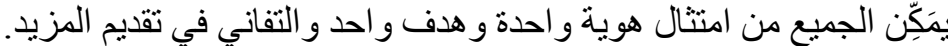

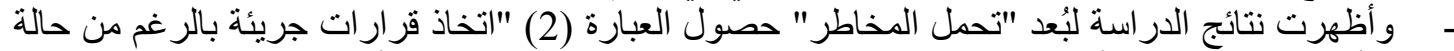

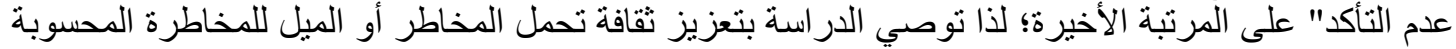

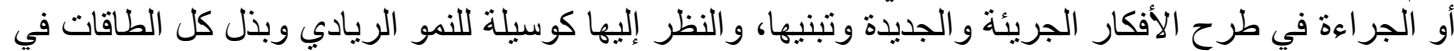
تحقيق الهدف غير المؤكد للوصول إلى النجاح المؤكد. من خلال إلهام العاملين بالجر اعة التنظيمية، والمرونة في

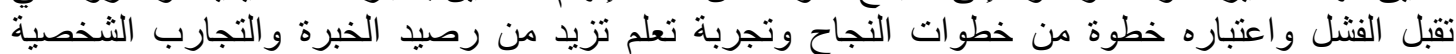
و التنظيمية، مع استقطاب الموظفين و أعضاء هيئة التدريس ذون ذوبي الثخصية المبادرة و القيادة الذاتية. 


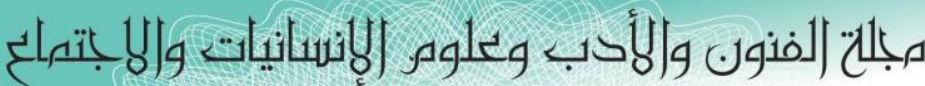

Journal of Arts, Literature, Humanities and Social Sciences

ISSN online: 2414 - 3383

ISSN print: 2616 - 3810

العدد (4O) توز - يوليو 2019

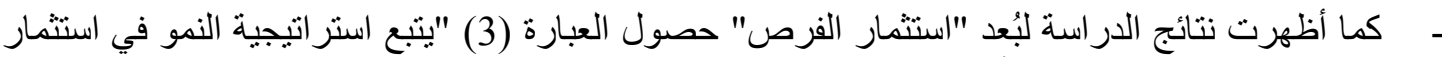

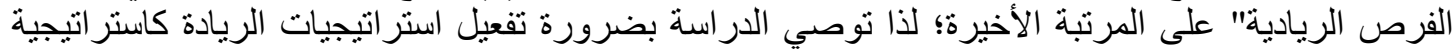

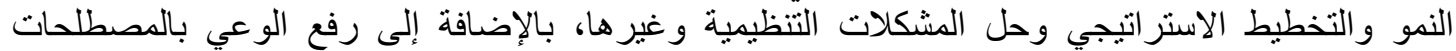
الريادية و الإدارية التي ترنقي بمستوى الأبن الأداء الوظيفي.

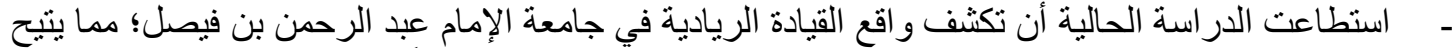

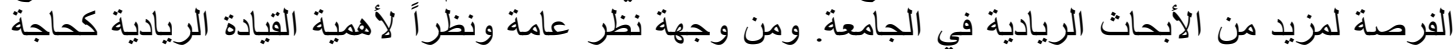

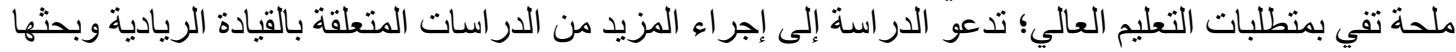
من زوايا مختلفة، وتوصي بعدد من الدراسات المستقبلية كما يلي: "القيادة الريادية كمدخل لتطوير القيادات

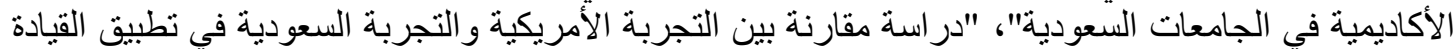

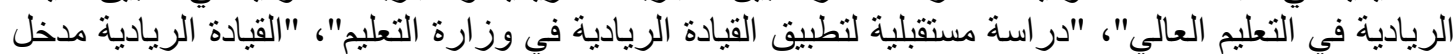

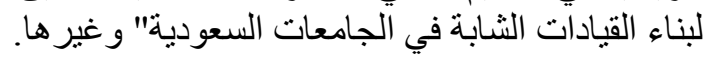

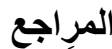

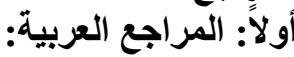

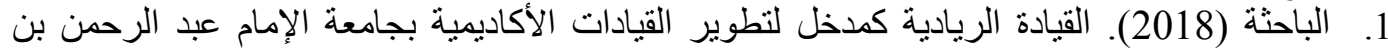
فيصل (رسالة ماجستير غير منشورة). جامعة الإمام عبد الرحمن بن فيصل، الإنة الدمام.

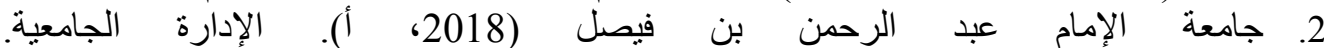
2018/10/10 2018//www.iau.edu.sa/ar/administration 3. جامعة الإمام عبد الرحمن بن فيصل (2018، ب). حصول الجامعة على التصنيف العالمي كأفضل في التصل

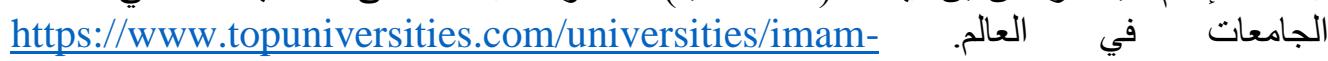
ت. abdulrahman-bin-faisal-university-iau-formerly-university-dammam

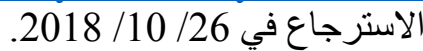
4. جامعة الدمام (1436). دليل التنظيم والتوصيف الوظيفي بجامعة الدمام. الرياض: مكتبة الملك فهر

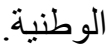

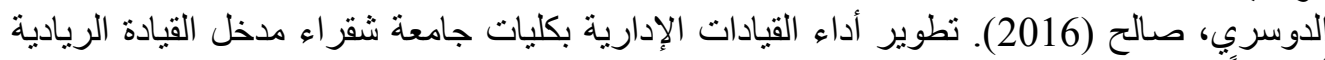

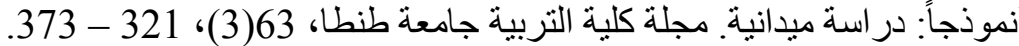

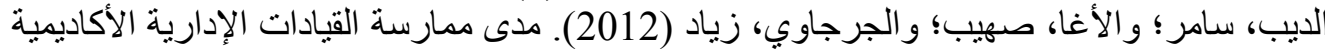

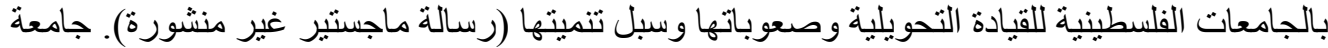

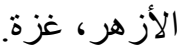

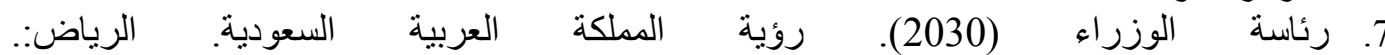
2018/4/29. http://vision2030.gov.sa/ar/node

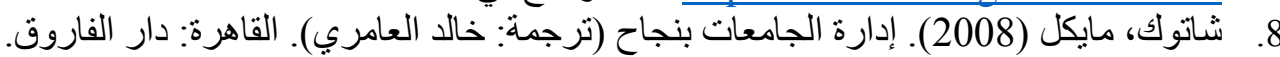

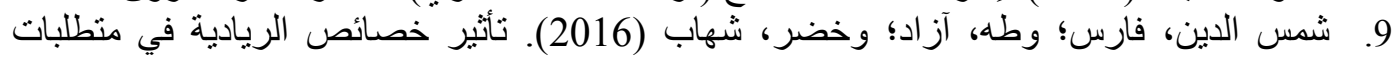

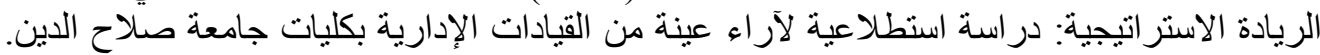

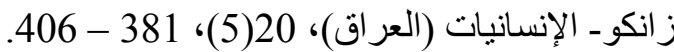
10. صائغ، عبد الرحمن (1432). التصنيفات الدانية الدولية للجامعات: تجربة الجامعات السعودية. المجلة

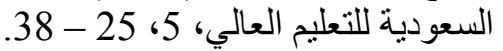
11. القحطاني، سالم (2015). القيادة الريادية وتطبيقاتها في الجامعات. الإدارة العامة (السعودية)، 55 .499- 435 ، (3)

12. معيقل، نورة (2016)، 435) تطوير أداء قيادات المدارس الثانوية في مشروع الملك عبد الله لتطوير التعليم

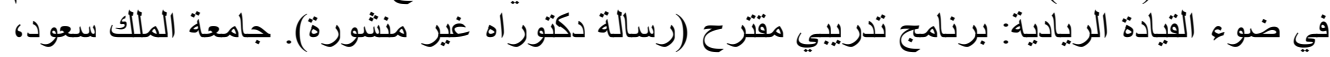



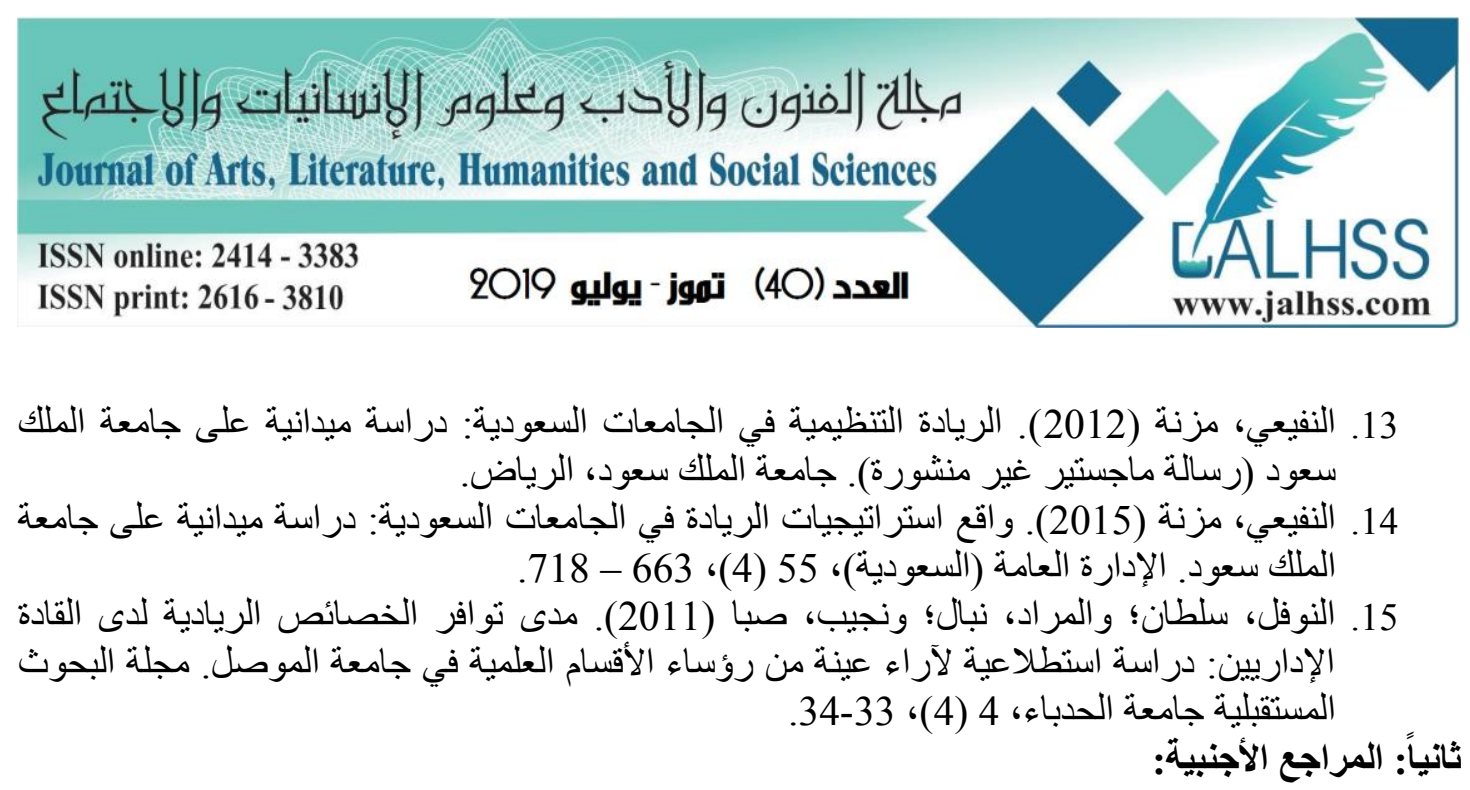

16. Asgarimehr, M., Shirazi, B., Iskandar, M. J., \& Rostami, S. (2012). A Strategic Framework for Designing E-Learning System with Focus on University Entrepreneurship. IJCSI International Journal of Computer Science Issues, 9(1), 1694-0814.

17. Beckman, G. D., \& Cherwitz, R. A. (2009). Intellectual Entrepreneurship: An Authentic Foundation for Higher Education Reform1. Planning for higher education, 37(4), 27.

18. Borasi, R., \& Finnigan, K. (2010). Entrepreneurial attitudes and behaviours that can help prepare successful change-agents in education. The new educator, 6(1), 1-29.

19. Byrne, P. D. (2013). Entrepreneurial leadership in higher education: Does the presidential career pathway make a difference? (Doctoral thesis, University of Missouri- Columbia). Retrieved from https://hdl.handle.net/10355/46115 .

20. Cleverley-Thompson, S. (2016). The Role of Academic Deans as Entrepreneurial Leaders in Higher Education Institutions. Innovative Higher Education, 41(1), 75-85.

21. Coyle, P. (2014). How entrepreneurial leadership can engage university staff in the development of an entrepreneurial culture. Industry and Higher Education, 28(4), 263-269.

22. Crute, C. D. (2010). Leading entrepreneurially: Understanding how community college leaders identify with and relate to entrepreneurial leadership. Mercer University.

23. Etzkowitz, H. (2008). The triple helix: university-industry-government innovation in action. New York: Routledge.

24. Floyd, D. L., \& Mulder, A. E. (2006). A Review of: "The Entrepreneurial Community College" By John E. and Barbara R. Jones (Eds.) Foreword by George R. Boggs. Journal Community College, 671-673. from https://doi.org/10.1080/10668920600843370.

25. Gibb, A., Haskins, G., \& Robertson, I. (2009). Leading the entrepreneurial university. University of Oxford.

26. Kuratko, D. F. (2003). Entrepreneurship education: Emerging trends and challenges for the 21st century. White Paper, US Association of Small Business Education, 22, 2003.

27. Neal, J. E. (1998). Quality assurance in the entrepreneurial university. New Directions for Institutional Research, 1998(99), 69-85.

28. Peck, R. D. (1983). The entrepreneurial college presidency. Educational Record, 64(1), 18-25.

29. Rohani, A. (2013). Entrepreneurship in sustainable development. Australian Journal of Basic and Applied Sciences, 7(2), 480-489.

30. Roueche, J. E., \& Jones, B. R. (Eds.). (2005). The entrepreneurial community college. American Association of Community College.

31. 


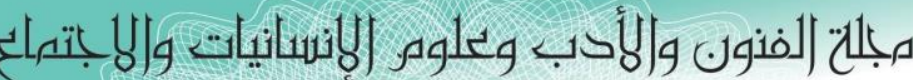

Journal of Arts, Literature, Humanities and Social Sciences

ISSN online: 2414 - 3383

ISSN print: 2616 - 3810

العدد (4O) توز - يوليو 2019

32. Utash, S. (2017). The Experiences of Community College Leaders Committed to an Entrepreneurial Leadership Philosophy (Doctoral thesis, National American University). Retrieved from: http://search.proquest.com/openview/a7ad7dff3f1c3db16181f774532c62ef/1?pqorigsite $=$ gscholar $\& \mathrm{cbl}=18750 \&$ diss $=y$

33. Wong, P. K., Ho, Y. P., \& Singh, A. (2007). Towards an "entrepreneurial university" model to support knowledge-based economic development: the case of the National University of Singapore. World Development, 35(6), 941-958. 